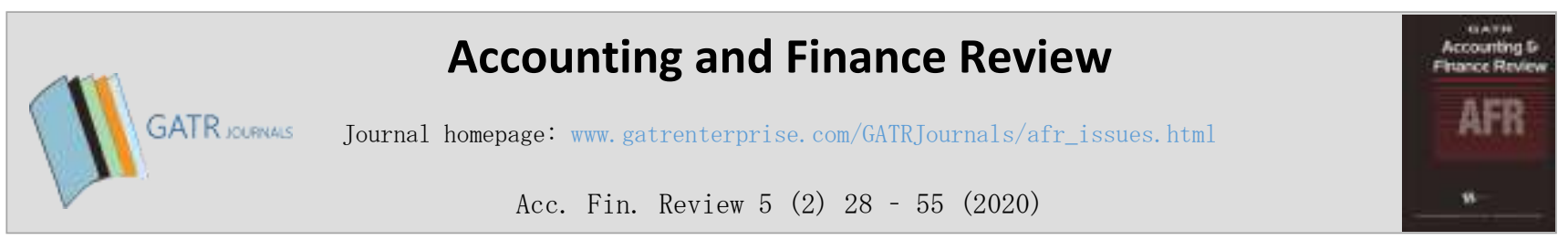

\title{
The Mystery of Zero-Leverage Firms: Evidence from Nigerian Quoted Firms
}

\author{
Oluseun Paseda Ph.D, ${ }^{* 1}$ Babatunji Samuel Adedeji Ph.D. $^{2}$ \\ ${ }^{1}$ Department of Banking and Finance, University of Ibadan, Nigeria. \\ ${ }^{2}$ Department of Accounting and Finance, School of Business and Economics, \\ Universiti Putra Malaysia.
}

\begin{abstract}
Objective - Empirical finance literature has added a new twist to the debt conservatism puzzle within the broader capital structure puzzle, namely the phenomenon of zero leverage. Motivated by Strebulaev and Yang (2013), this study investigates the attributes of zero leverage firms in Nigeria in an attempt to add a developing country perspective to the zero-leverage phenomenon observed in firms.

Methodology/Technique - The non-financial corporations quoted on the Nigerian Stock Exchange (NSE) for the period 1999-2014 constitute the population of the study. Firms with market leverage ratios ranging from $0 \%$ to $5 \%$ met the criteria for inclusion. Panel data regression techniques such as the generalized method of moments (GMM) and two stage least squares (2SLS) were used in the study.

Findings - Zero leverage is persistent across 13 industries and is a declining function of the marginal tax rate, firm size, profitability, and liquidity. Firms that follow a zero-leverage (and almost zero-leverage) policy have higher growth opportunities, more tangible assets, pay higher dividends, are older, and have access to debt markets. Non-debt tax shields do not explain zero-leverage behaviour.

Originality/Value - This study addresses the gaps related to the questions of why and how firm-specific attributes affect zero leverage behaviour among Nigerian quoted firms. It sheds light on the economic mechanisms driving zero leverage phenomenon within firms with high debt capacity.

Type of Paper: Empirical.
\end{abstract}

JEL Classification: G30, G32.

Keywords: Capital Structure; Zero Leverage Puzzle; Tax Benefits; Debt Capacity; Financing Decisions.

Reference to this paper should be made as follows: Paseda, O; Adedeji, B.S. (2020). The Mystery of Zero-Leverage Firms: Evidence from Nigerian Quoted Firms, Acc. Fin. Review, 5 (2): 28 - 55. https://doi.org/10.35609/afr.2020.5.2(2)

\section{Introduction}

Debt conservatism is an essential new puzzle that has emerged within the broader category of capital structure literature.

\footnotetext{
* Paper info: Revised: June 17, 2020

Accepted: September 30, 2020

* Corresponding author: Oluseun Paseda,

E-mail: seunpash@yahoo.com

Affiliation: Department of Banking and Finance, University of Ibadan, Nigeria.
} 
The financial theory should be able to explain why large, profitable, and massive tax-paying firms do not fully exploit the potential tax savings generated by debt. At best, partial explanations exist for this debt conservative behavior such as avoidance of debt overhang or underinvestment problems (Myers, 1977), pecking order financing (Myers \& Majluf, 1984; Lambrecht \& Myers, 2017) and agency cost of debt considerations (Jensen, 1986; Jensen \& Meckling, 1976).

It has been more than two decades after Myers (1977) and Graham (2000:1901) first asked the questions, "Do the tax benefits of debt affect corporate financing decisions? How much do they add to firm value?" and found that "Growth firms that produce unique products use debt conservatively," but "surprisingly, large, profitable, liquid firms also use debt sparingly..." An even more significant challenge is posed to existing theories and intensifies the debt conservatism puzzle in the capital structure literature. Graham (2000) quickly concludes that "there are many unanswered questions as to why some firms appear to be underleveraged. This area is fertile ground for future research" (Graham, 2000:1935). Graham and Tucker (2006) attempt to explain the debt conservatism puzzle through an investigation of the role of off-balance sheet tax shelters. They found that firms that use tax shelters use less debt on average than non-shelter firms. Their results are consistent with the view that those tax shelters act as non-debt tax shields that substitute for the use of interest tax deductions obtainable from debt financing (DeAngelo \& Masulis 1980). Cohn, Titman and Twite (2020) examined a court ruling that materially affected taxation in several European countries and found "that leverage ratios change little on average but increase substantially for capital-raising firms which should be the most affected by the tax changes."

There is a precautionary view for debt conservatism, as in Ayyagari, Beck and Hoseini (2020), DemirgucKunt, Peria and Tressel (2020), and Kim (2020). Nevertheless, this view is, at best, a partial rationale for low leverage ratios. Indeed, a small debt puzzle persists (Myers, 2001; Barclay \& Smith, 2020). Strebulaev and Yang (2013) investigate extreme debt conservatism behaviour in which large profitable US non-financial corporations do not use debt at all - the so-called "zero-leverage" phenomenon. The finding was that "firms (and more so, dividend-paying firms) that prefer to eschew debt are profitable, exhibit large tax payments, accumulate large cash balances, and payout larger dividends. They replace interest payments with dividends and stock repurchases (Strebulaev \& Yang, 2013:11).

Moreover, many empirical papers on capital structure tests have focused on developed markets where capital market frictions may differ in nature from the imperfections in the developing capital markets. A central concern of scholars has been the examination of how specific market frictions - such as taxes, transaction costs, information asymmetries and bankruptcy costs - alter the central predictions of Modigliani and Miller (MM, 1958). Specifically, the presence of tax-induced frictions in developing countries suggests that emerging markets provide an excellent laboratory for capital structure tests that incorporate the impact of market frictions. This paper is motivated by these factors.

Soyode (1978), Amah and Ezike (2013), and Amah (2014) provide a developing country perspective to the apparent debt-conservatism of firms. Specifically, Amah and Ezike (2013) repeated Miller's (1977) question as to the divergence of tax benefits from bankruptcy costs to rationalize apparent debt conservatism. Though bankruptcy and agency costs may discourage borrowing, Amah and Ezike (2013) question whether these costs are large enough to be significant. As profound and robust as the observation of actual debt ratios of Nigerian corporations seem, they are less than the theoretical optimal levels, and the robust econometric analysis of the impact of financial leverage on corporate valuation. The research did not explicitly consider how the economic mechanisms that they studied drive firms towards extreme debt conservatism of zeroleverage.

Post-MM capital structure studies have concentrated on testing the predictions of competing theories of capital structure such as pecking order, trade-off, agency, and market models. There is no doubt some truth in each of these theories, but they do not add up to a rigorous, complete, and conclusive explanation of a zerodebt policy. However, their validity is challenged by society (Zingales, 2015). This study seeks to add a 
developing country perspective to the zero-leverage puzzle and thus fill an essential gap in corporate finance literature.

Based on institutional characteristics, the level of tax enforcement or compliance in an economy may be indicative of a firms' propensity to utilize debt to minimize their tax liabilities. Weak administration and substantial-scale tax avoidance or evasion may exist due to low ratios of 'tax revenue to GDP'. Firms may not experience any real risk of detection or punishment due to the evasion of taxes. Shleifer and Vishny (1993), for example, reiterate the possibility of the above situation concerning in many developing nations, where public pressure on corruption or the enforcement ability of government is relatively weak. A sizeable parallel economy with unrecorded and undisclosed incomes may evolve because of low ratios. The presence of incentives for companies to exploit loopholes in existing tax laws and enforcement practices should make this line of capital structure research an exciting one in an emerging market (Adelegan, 2009; Adelegan \& Ariyo, 2008). Fan, Titman and Twite (2012) found that a country's legal and tax system and corruption, among other factors, explains a significant portion of the variation in leverage and debt maturity ratios. Barclay and Smith (2020) provide similar results.

The reason for this study is to explore the features of zero-leverage and almost zero-leverage firms in Nigeria. A study of the determinants of the zero-leverage phenomenon helps to uncover the economic mechanisms that lead firms to become low-leverage as such factors are likely to be dominant for zero-debt firms. Hence, the critical outcome of this paper is that firms that implement zero leverage (and almost zero leverage) policies have higher growth opportunities because their ratio of market-to-book value of equity has a higher number of tangible assets. They also pay higher dividends, are older, and have debt market access based on a rating dummy. The analysis also reveals that debt substitutes (or non-debt tax shelters) cannot account for zero-leverage behaviour. In sum, these results provide a profound developing country perspective of the assertion by Graham (2000) and similar subsequent papers that many profitable firms seem to be underleveraged.

The structure of the rest of this paper is as follows: Section 2 reviews prior work on zero-leverage behaviour observed in firms. Section 3 delves into the data and methodology for this study, including data description, sample construction, and the definition of the variables. Section 4 presents and discusses the empirical results of the impact of firm attributes of the marginal tax rate, non-debt tax shelters, assets tangibility, growth opportunities, size, earnings volatility, profitability, liquidity, assets' riskiness, dividend payout, age and rating dummy on the zero-leverage phenomenon. Section 5 discusses the implications of the results, and the final section concludes the paper.

\section{Prior Literature on the Zero-Leverage Puzzle}

The Modigliani-Miller (MM 1958, 1963) papers' central result is that, in a setting with complete and perfect capital markets, a firm's total market value is invariant to its borrowing behaviour. When corporate tax is included in the analytical framework, then optimal leverage occurs at a theoretical $99.9 \%$ debt ratio. The powerful results demonstrated by their arbitrage proof points to the direction that corporate finance theories must follow by showing under what conditions capital structure is irrelevant (Graham \& Leary, 2011; Paseda, 2016; Alter \& Elekdag, 2020; Barclay \& Smith; Ferres, Ormazabal, Povel \& Sertsios, 2020; Gale \& Gottardi, 2020; Kim, 2020). With the perspective provided by asset pricing theories (Sharpe, 1964; Lintner, 1965; Mossin, 1966; Black, 1972; Lucas 1978; Breeden, 1979 and others) which were unavailable to MM, their propositions do not require their highly restrictive risk classes. An open challenge in corporate finance is to produce evidence on how taxes affect market values and, thus, optimal financing decisions (Fama, 2011). Why are highly profitable firms using debt conservatively in the face of potential tax benefits - this is the low leverage puzzle in finance. An extreme version of this puzzle is the zero-leverage phenomenon analysed for the US market by Strebulaev ad Yang (2013). This section reviews the various explanations for zero-leverage behaviour in corporate financing. 


\subsection{Theoretical Framework}

The study of the zero-leverage phenomenon is essential. Strebulaev and Yang (2013), opine that zero leverage and almost zero leverage (book and market leverage ratios not more significant than 5\%) are essential for a better comprehension of capital structure decision-making activities. The resemblance is to the much-studied debt conservatism or low leverage mystery, which is the established fact that, on average, firms are under-levered relative to their theoretical or actual debt capacities. Various academic works address the low leverage puzzle by considering the economic forces driving conservative capital structure downwards and even to zero. Such economic forces driving low leverage behaviour may display less dominance in the zero-levered firms and are thus convenient to recognize when zero-levered firms are studied. There are two broad explanations of debt policies, namely: tax-based factors and non-tax-based factors.

When tax-based theories are reviewed concerning conservative debt policies, it may be essential to investigate whether zero-levered firms leave so much value on the table through the tax benefits of debt that they eschew (Modigliani \& Miller, 1963; Miller, 1977; Graham, 2000). The tax benefits of debt are the tax savings that result from deducting interest before taxable earnings are derived. Thus, the higher the potential interest deductions before earnings chargeable to tax, the higher the potential tax savings, which could increase the market value of the firm (Doidge \& Dyck, 2015; Scholes et. al., 2015).

With the introduction of personal taxes into the analytic framework (Miller, 1977), the corporate tax advantage of debt is either fully offset so that there is no benefit to corporate borrowing as in the Miller equilibrium. Alternatively, it can be partially offset by the personal tax penalty of debt financing, as in Graham (2000) and related papers.

The non-taxed based factors that influence debt policy include the expected costs of financial distress, the availability of investment or growth opportunities, managerial entrenchment, and private benefits. Others include asset riskiness or intangibility, firm size, asset collateral, information asymmetry between corporate insiders and outside investors, financial flexibility, product market and industry effects (such as industry concentration and product uniqueness), profitability, cash flows, and liquidity, and earnings or cash flow volatility.

From the financial theory, firms that face enormous ex-ante financial distress costs seem to use debt sparingly with the assumption of having lower debt ratios (Barclay, Morellec \& Smith, 2006; Korteweg, 2010; Glover, 2016). Growth firms - firms with abundant investment opportunities - should also use debt sparingly to avert the familiar under-investment problem (Myers, 1977). Growth is measured in this study by the ratio of market-to-book value of the firm, also known as Tobin's q. Using the market-to-book ratio overcomes the vagueness attributable to the price-earnings $(\mathrm{P} / \mathrm{E})$ ratio as a competing indicator of growth (Akintola-Bello, 2004). In terms of executive entrenchment and secluded benefits of control, firm executives may prefer traditional debt strategies to maximize their utility functions instead of optimizing the shareholders' value. Firms with more risky and intangible assets are more likely to use debt conservatively because these firms also face enormous ex-ante costs of financial distress (business risk) that could be complicated by aggressive borrowing. Research and development expenditure, as well as other intangible assets contained in firms' statements of financial position, are used as a measure of asset riskiness in this study.

In terms of firm size, small firms, when borrowing funds, usually encounter higher informational costs. Further, smaller firms may experience high ex-ante costs of financial weakness, especially if they cannot afford to diversify in a manner that their investors could not have replicated (Giambona, Graham, Harvey \& Bodnar, 2018; Hecht, 2019; Buckley, Chen, Clegg \& Voss, 2020). Small firms may also have lower debt capacity, particularly if their size is closely associated with lower tangible assets-in-place. Larger mature firms with a high level of liquidity but with fewer investment opportunities can borrow more than small (growth) firms whose positive net present value (NPV) investments exceed internally generated funds 
(Oyelakin, 2020). Small growth firms will be cautious in the use of debt to avoid debt overhang and underinvestment problems.

In terms of a size measurement, recent research such as Dang, Li and Yang (2018) has shown that empirical corporate finance results are sensitive to different measures of size. This research uses the natural logarithm of sales as a proxy for firm size because the researcher opines that this measure is more relevant for studying capital structure choices than its competing alternatives, such as total assets and market capitalization. Of course, a firm with valuable asset collateral can often borrow more on relatively favourable terms and hence will have lower borrowing costs, which may result in more aggressive borrowing. Asset collateral is measured using the tangible assets ratio, such as property plant and equipment, to total assets.

In relation to information asymmetry between corporate insiders and outside investors, Myers and Majluf (1984) opine that managerial incentives to issue overvalued securities is traceable to the availability of asymmetry information. However, security issuance produces negative a reaction due to rational expectations, which the market anticipates. Thus, firms prefer to issue securities in reverse order to minimise the adverse market reaction based on the extent of informational sensitivity resulting in pecking order: internal equity or retained earnings, straight external debt, convertible securities, and as a last resort, external equity. The argument is that low and especially non-dividend-paying firms are subject to substantial informational asymmetries (for instance, in Renneboog \& Szilagyi, 2020 and Choi, Park \& Kim, 2020) that could cause them to use more debt than equity in financing matters. The dividend is measurable by the payout ratio, which is calculated as the ratio of dividends to after-tax earnings.

In terms of financial flexibility, corporate surveys such as Graham and Harvey (2001) and Giambona, Graham, Harvey and Bodnar (2018) argue that firms sparingly use debt to sustain financial flexibility for the future investment programs. Thus, this may rationalize the low leverage puzzle.

Along with product market and industry effects, industry concentration, and product uniqueness, influence capital structure choice, and liquidity (Lin, Schmid \& Weisbach, 2020). There is a competitive advantage over highly levered rivals by monopolies and firms in monopolistic markets. They could exploit this advantage through competitive pricing of goods and services and, in extreme situations, snowball to gain increased market share.

Further, debt is conservatively used by firms that produce unique products. If a different product firm ceases to be a going concern, its closure imposes relatively huge costs on the firm's business contact groups such as customers, suppliers, and employees. A firm's unique servicing requirements of its product adversely affect its customers and also its suppliers as well as the employees due to the product-specific skills and capital they have (Elkahmi \& Salerno, 2020). This study uses dummy variables to account for uniqueness thus, one of the firm is in chemical, computer, or aircraft or any other related sensitive industry, which is the only firm falling within this category.

The impact of profitability on leverage is ambiguous. Firms in high-income tax brackets may choose to use leverage to minimise their corporate tax bill by taking advantage of tax savings that result from interest deductions. The result will be profitable firms using debt more aggressively according to the trade-off theory of capital structure. On the other hand, in the presence of information asymmetries, profitable firms may choose to utilize internally generated funds or retained earnings to fund capital expenditure programs and use excess cash flow to retire debt according to the pecking order model of Myers (1984) and Myers and Majluf (1984). In this framework, profitable firms use debt sparingly because they do not need outside funds, and internal equity is least informationally sensitive.

Myers (2001) notes that a pervasive empirical capital structure regularity is the inverse relationship between debt usage and profitability, as in Fama and French (2012) and Lambrecht and Myers (2017). It is important to note that an inverse profitability-leverage relationship may become accommodated under a dynamic trade-off model. Profitability in this study is measured using the return on capital employed, defined as the ratio of operating earnings to capital employed. In addition, firms with more volatile earnings or cash flows are to use debt with greater caution so that leverage can have an inverse relationship with volatility 
(Choi \& Richardson, 2016; Bianchi, Ilut \& Schneider, 2018). Nonetheless, volatility is measured as the standard deviation of operating earnings.

In relation to liquidity, illiquid firms face high ex-ante borrowing costs, being the basic opinion expressed in literature. However, there is a paradox of liquidity in that under certain conditions; liquid firms have a harder time credibly committing to a specific line of action. In this situation, the cost of external finance is higher. Free cash flow considerations can counterbalance the liquidity effect. Jensen (1986) posits that executives of mature firms with fewer investment opportunities might lack discipline even with abundant cash flows. An implication of this free cash flow theory of Jensen is that firms should issue debt, thereby committing to "disgorge" free cash flows as interest payments to discipline management into working efficiently.

Indeed, Admati, DeMarzo, Hellwig and Pfleiderer (2018) demonstrate that incumbent shareholders are hurt by leverage-reducing recapitalizations and thus would not voluntarily choose to engage in it. With these shareholders, their resistance to debt reduction is much more potent than the underinvestment problem identified by Myers (1977). The measure of liquidity in this study is achieved using the acid test ratio (also quick ratio).

\subsection{Methodological Review}

The most common method for investigating dynamic capital structure choice in the empirical literature is regression analysis. Structural models that embed endogeneity concerns are becoming common in empirical corporate finance (Eisenthal-Berkovitz, Feldhutter \& Vig, 2020). Looking at corporate capital structure choice through the lens of a dynamic structural model helps to address questions that may be difficult to tackle in a static framework. One particular advantage of utilizing dynamic models is that they provide quantitative rather than qualitative implications for the study on a capital structure where, for instance, the relative costs and benefits of leverage have been at the center of much of the research agenda.

Specifically, a specific methodology used in the literature is the generalized method of moments (GMM). The GMM estimators are consistent, asymptotically regular, and efficient in the class of all estimators. They are appropriately robust to overcome endogeneity problems. Asymptotic normality is a useful property as it allows researchers to construct confidence bands for the estimator and conduct different tests.

Strebulaev and Whited (2012) provide a comprehensive review of dynamic corporate finance models, including those applied to capital structure investigations such as debt conservatism, dynamic trade-off models, and target adjustment hypothesis. Using some of these dynamic models, Lotfaliei (2020) attempts to combine insights from asset pricing theory into capital structure choice through the examination of the impact of the asset-return variance risk premium on leverage. He established "that the premium reduces leverage by increasing risk-neutral bankruptcy probability and costs."

\subsection{Empirical Review}

Many empirical studies are available on the study of capital structure, including some of the papers mentioned above, and it is difficult to review all the significant articles here. Hence, an attempt is made here to document some key findings from the empirical literature on capital structure research and the economic mechanisms driving capital structure choice as shown in Table 1 below.

Table 1. Empirical Review of Capital Structure Studies Including the Low-leverage Puzzle

\begin{tabular}{|c|c|c|c|}
\hline SN & STUDY & METHODOLOGY & MAIN FINDINGS \\
\hline 1 & Fama \& French & $\begin{array}{c}\text { Sample: 3000 firms for the } \\
\text { period 1965- 1999; Estimation } \\
\text { procedures: pooled time-series } \\
\text { cross-section (panel) regressions. }\end{array}$ & $\begin{array}{c}\text { More profitable firms and firms with fewer investments have } \\
\text { higher dividend payouts confirming predictions shared by the } \\
\text { trade-off and pecking order models. More profitable firms are } \\
\text { less levered confirming the pecking order model but }\end{array}$ \\
\hline
\end{tabular}




\begin{tabular}{|c|c|c|c|}
\hline & & & $\begin{array}{l}\text { contradicting the trade-off model. The trade-off model and a } \\
\text { complex pecking order mode are consistent in affirming that } \\
\text { firms with more investments have less market leverage. } \\
\text { Short-term variation in investment and earnings is mostly } \\
\text { absorbed by debt, confirming the pecking order model. }\end{array}$ \\
\hline 2 & $\begin{array}{l}\text { Frank \& Goyal } \\
(2008,2009)\end{array}$ & $\begin{array}{l}\text { Sample: publicly traded } \\
\text { American firms excluding } \\
\text { financial firms, regulated } \\
\text { utilities, and firms involved in } \\
\text { significant mergers over the } \\
\text { period 1950-2003. A market- } \\
\text { based definition of leverage } \\
\text { helps to examine the most } \\
\text { critical factors affecting } \\
\text { leverage. Estimation technique: } \\
\text { Panel data Regressions }\end{array}$ & $\begin{array}{l}\text { They document that the most decisive factors for explaining } \\
\text { market leverage are: median industry leverage (+ effect on } \\
\text { leverage), market-to-book assets ratio (-), tangibility (+), } \\
\text { profitability (-), a log of assets (+), and expected inflation (+). } \\
\text { Also, they find that dividend-paying firms tend to have lower } \\
\text { leverage. The net equity issues track the financing deficit } \\
\text { more closely than do net debt issues contrary to the view of } \\
\text { the pecking order model. The evidence is not robust to the } \\
\text { inclusion of common leverage factors, nor the analysis of } \\
\text { evidence from the 1990s but large firms exhibit some aspects } \\
\text { of the pecking order behavior. Financing deficit is not } \\
\text { adequate for explaining net debt issues for firms of all sizes. }\end{array}$ \\
\hline 3 & Abor (2008) & $\begin{array}{l}\text { The sample consists of publicly } \\
\text { quoted firms, large unquoted } \\
\text { firms, and small and medium } \\
\text { enterprises (SMEs) in Ghana. } \\
\text { Utilised for the study was the } \\
\text { Panel data regression techniques } \\
\text { were. }\end{array}$ & $\begin{array}{l}\text { The results show that quoted and large unquoted firms exhibit } \\
\text { significantly higher debt ratios than do SMEs, and there is no } \\
\text { significant difference between the capital structures of } \\
\text { publicly quoted firms and large unquoted firms. Also, firm- } \\
\text { specific factors that influence capital structure decisions } \\
\text { include firm age, size, asset structure, profitability, risk, and } \\
\text { managerial ownership. }\end{array}$ \\
\hline 4 & $\begin{array}{c}\text { Hartmann- } \\
\text { Wendels, Stein } \\
\text { \& Stoter (2012) }\end{array}$ & $\begin{array}{l}\text { Using a sample of } 80,000 \\
\text { German firms throughout } 1973- \\
2008 \text {, the authors utilized OLS } \\
\text { pooled regressions to examine } \\
\text { the determinants of leverage. } \\
\text { Utilised to capture the tax effects } \\
\text { on the capital structure was } \\
\text { Graham's marginal tax rate } \\
\text { approach. }\end{array}$ & $\begin{array}{l}\text { Empirical result documents a significant positive relationship } \\
\text { between the marginal tax benefit of debt and the debt ratio of } \\
\text { German firms. After controlling for conventional leverage } \\
\text { determinants, they find that a } 10 \% \text { increase in the marginal } \\
\text { tax benefit of debt at the corporate level (investor level) } \\
\text { causes a } 1.5 \%(1.6 \%) \text { increase in debt ratio, ceteris paribus. } \\
\text { This positive relationship was present in various alternative } \\
\text { specifications (like changes in debt levels or a net increase of } \\
\text { debt) and a partial adjustment model. }\end{array}$ \\
\hline 5 & $\begin{array}{l}\text { Strebulaev \& } \\
\text { Yang (2013) }\end{array}$ & $\begin{array}{c}\text { Sample: US non-financial } \\
\text { companies in the CRSP } \\
\text { Compustat database for the } \\
\text { period 1962-2009. Zero leverage } \\
\text { firms are firms with zero book } \\
\text { debt, i.e., both short- and } \\
\text { longterm debt equal to zero. } \\
\text { Utilised were the OLS } \\
\text { Regressions and Logit } \\
\text { Regressions. }\end{array}$ & $\begin{array}{l}\text { A substantial number of large public non-financial US firms } \\
\text { follow a zero-debt or almost zero-debt policy. The authors } \\
\text { show this as a puzzling evidence. Nearly } 22 \% \text { have less than } \\
5 \% \text { book leverage ratio, and on the average, } 10.2 \% \text { of such } \\
\text { firms have zero leverage. Such behavior cannot fully be } \\
\text { explained by neither industry nor size. The presence of a large } \\
\text { number of these that pay dividends produce more surprises. } \\
\text { Firms chosen by industry and size as proxies perform less } \\
\text { than the zero-leverage dividend-paying firms that are more } \\
\text { profitable, pay higher taxes, and have higher cash balances. } \\
\text { The latter firms are also more liberal in their dividend payout } \\
\text { than their proxies, thus, payout ratio is relatively independent } \\
\text { of leverage. }\end{array}$ \\
\hline 6 & $\begin{array}{l}\text { Gathogo \& } \\
\text { Ragui (2014) }\end{array}$ & $\begin{array}{l}\text { Sample firms include public } \\
\text { quoted firms, large unquoted } \\
\text { firms, and SMEs. Utilised was } \\
\text { the Panel Data Regression } \\
\text { technique. }\end{array}$ & $\begin{array}{l}\text { Firm-specific factors exert the following influences on capital } \\
\text { structure choice viz: size (+ve), age (+ve), profitability (-ve), } \\
\text { liquidity (-ve), cost of debt (-ve), business risk (- ve) and } \\
\text { industry type (-ve). }\end{array}$ \\
\hline 7 & $\begin{array}{c}\text { Begenau \& } \\
\text { Salomao (2019) }\end{array}$ & $\begin{array}{l}\text { Examined financing decisions of } \\
\text { US public quoted firms under a }\end{array}$ & $\begin{array}{c}\text { During booms, large mature firms finance with debt and } \\
\text { payout equity. However, because of their high risks and, at }\end{array}$ \\
\hline
\end{tabular}




\begin{tabular}{|c|c|c|c|}
\hline & & $\begin{array}{c}\text { dynamic trade-off model. The } \\
\text { study utilized dynamic panel } \\
\text { data models }\end{array}$ & $\begin{array}{c}\text { the same time, higher funding needs, smaller unprofitable } \\
\text { firms must deal with higher financing frictions. In the case of } \\
\text { both debt and equity, small firms adhere to procyclical } \\
\text { financing policy whereas large firms in managing financing } \\
\text { cycles generally substitute between debt and equity. }\end{array}$ \\
\hline 8 & $\begin{array}{c}\text { Antill \& } \\
\text { Grenadier (2019) }\end{array}$ & $\begin{array}{c}\text { US public firms using dynamic } \\
\text { models of optimal capital } \\
\text { structure in the presence of } \\
\text { default costs }\end{array}$ & $\begin{array}{c}\text { The off-equilibrium threat of costly reorganization can exert } \\
\text { downward pressure on leverage with liquidation in } \\
\text { equilibrium. If restructuring is less efficient than liquidation, } \\
\text { the reorganization option reduces shareholders' wealth ex- } \\
\text { ante. }\end{array}$ \\
\hline 9 & $\begin{array}{c}\text { Elkamhi \& } \\
\text { Salerno (2020) }\end{array}$ & $\begin{array}{c}\text { Examined Canadian public firms } \\
\text { using a dynamic trade-off model } \\
\text { of capital structure }\end{array}$ & $\begin{array}{c}\text { The authors found that pre-default costs are, on average equal } \\
\text { to 6.5\% of the firm value per year, which translates into } \\
\text { approximately 5.5\% of the ex-ante firm value. Accounting for } \\
\text { pre-default costs improves the portability of the trade-off } \\
\text { model significantly. }\end{array}$ \\
\hline 10 & Sarkar (2020) & $\begin{array}{c}\text { Examined Australian and New } \\
\text { Zealand firms using dynamic } \\
\text { panel data models }\end{array}$ & $\begin{array}{c}\text { Financial leverage is a monotonically decreasing function of } \\
\text { operating leverage when the latter is independently specified. } \\
\text { The operating leverage will initially increase and } \\
\text { subsequently falling in financial leverage when the financial } \\
\text { leverage is exogenously determined. There is usually no } \\
\text { substitute behavior between operating leverage and financial } \\
\text { leverage. }\end{array}$ \\
\hline
\end{tabular}

Source: Updated from Paseda (2016)

\section{Methodology}

\subsection{Design}

This study focuses on an aspect of capital structure viz-a-viz zero-leverage behaviour of firms. Based on a careful review of the literature and an earlier empirical work conducted by Paseda (2016) where the economic mechanisms driving capital structure choice of Nigerian quoted firms became evaluated, this study builds on that work. This research sorts the market leverage ratios of the firms from smallest to largest and extracts those firm years with ratios not higher than 5\%. Firm years with market leverage ratios of zero correspond to zero leverage behaviour. In contrast, those years with market leverage ratios of 5 percentage points and less correspond to almost zero-leverage behaviour.

\subsection{Data and Sample}

This study uses secondary data obtained from the Nigerian Stock Exchange (NSE) and annual financial statements of the quoted firms. The population for this study is the Nigerian quoted companies with zero leverage behaviour for the period of 16 years from 1999 to 2014. The year 1999 was chosen as start year to situate the sample period to the transition from military rule to democratic or civilian rule in Nigeria whereas the year 2014 was chosen in an attempt to balance the panel data because a good number of the sample firms' annual reports were not available to allow a further update when the analysis was conducted. There were 158 quoted companies in Nigeria as of December 2019. The listing of equities is under 20 broad industry sectors.

Further adjustment is necessary to derive the sample firms. The sample excludes firms from the financial services sector because of the specific rules they have to comply with (e.g., Banks and Other Financial Institutions Act (BOFIA, 1991)), and the unique high-leverage nature of financing, which is severely affected by exogenous factors (Miller, 1995; Miller, 2005). Therefore, following empirical patterns (such as Rajan \& Zingales, 1995), the research focuses exclusively on non-financial corporations. There is therefore a stratification of the sample concerning companies selected for the study, as displayed in Table 2 below. 
Accordingly, the sample is representative data, and there is no reason to believe that sample selection biases affected the results.

Table 2. Sample of Study by Sector

\begin{tabular}{|c|c|c|c|c|}
\hline $\mathrm{S} / \mathrm{N}$ & Sector & Population & Sample & Sample-population ratio (\%) \\
\hline 1 & Agriculture & 6 & 4 & 66 \\
\hline 2 & Aviation/Airline & 2 & 1 & 50 \\
\hline 3 & Automobile \& Tyre & 3 & 2 & 66 \\
\hline 4 & Breweries & 7 & 3 & 43 \\
\hline 5 & Building Materials & 7 & 3 & 43 \\
\hline 6 & Chemical and Paints & 9 & 4 & 44 \\
\hline 7 & Computer & 6 & 1 & 17 \\
\hline 8 & Conglomerate & 8 & 4 & 50 \\
\hline 9 & Construction/Real & 6 & 3 & 50 \\
\hline 10 & Engineering & 3 & 1 & 33 \\
\hline 11 & Food and Beverages & 18 & 6 & 33 \\
\hline 12 & Health Care & 12 & 5 & 42 \\
\hline 13 & Hotels and Tourism & 4 & 1 & 25 \\
\hline 14 & Industrial/Domestic & 10 & 4 & 40 \\
\hline 15 & Oil and Gas & 9 & 5 & 56 \\
\hline 16 & Packaging & 8 & 0 & 0 \\
\hline 17 & Publishing & 4 & 2 & 50 \\
\hline 18 & Road Transport & 1 & 1 & 100 \\
\hline \multirow[t]{2}{*}{19} & Textiles & 3 & 0 & 0 \\
\hline & Total & 126 & 50 & 40 \\
\hline
\end{tabular}

Source: Underlying Data from the Nigerian Stock Exchange Factbooks (Various Years).

\subsection{Model Specification and Estimation Procedures}

The functional model of the leverage equation is Dit $=\mathrm{f}$ (Xit) where Dit is the leverage measure and Xit is the vector of firm-level covariates. Following empirical approaches, the implicit model is as follows:

\section{MODEL:}

Dit=f(MTRit, NDTSit, SIZEit, TANGit, GROWit, VOLit, PROFit, RDit, QUICKit, DIVit, AGE, RATit)

Explicitly, with $\mathrm{X}$ as a vector of explanatory variables,

Dit $=\beta 0+\beta \mathrm{xXit}+\varepsilon$

H02: $\beta$ MTR $=0 ;$ H12: $\beta$ MTR $\neq 0$. Trade off theory especially predicts $0<\beta$ MTR $<1$.

H01: $\beta$ 's $=0$; alternatively, H11: $\beta$ 's $\neq 0$. 
Where Dit represents the leverage measure for firm $i$ at time $t$. For all the variables, except expected inflation, the subscripts can be interpreted that each exogenous factor is for firm $i$ at time t. The independent variables could be taken contemporaneously or may have lagged in one period. Both methods are acceptable in empirical corporate finance.

The debt ratio defined as "the ratio of total liabilities to total liabilities plus equity" is the chosen leverage measure for this study. This measure is equivalent to the "total liabilities to assets ratio" being advocated in Welch $(2011,2015)$. Three measures of debt ratio are employed, namely: Book Leverage, Market leverage capturing only financial liabilities (ML1t), and Market leverage capturing all liabilities in the balance sheet (ML2t). ML1t is the financial leverage ratio, while ML2t is the total leverage ratio. All the chosen leverage measures are stock-based methods.

This study utilizes panel data estimation techniques of Generalized Method of Moments (GMM) model, Two-Stage Least Squares (2SLS) and Generalized Auto-regressive Conditional Heteroscedasticity (GARCH). The well known merits of the GMM model include its ability to resolve endogeneity and simultaneity problems in empirical estimations which linear regression methods such as the ordinary least squares (OLS) struggle with. In addition, GMM estimator is more efficient than the OLS estimator and difference estimators as it reduces the loss of valuable information arising from transformation of variables such as in difference estimators. The GARCH addresses the issue of changing variance of the serial disturbance term thereby making the GMM estimation results more robust and reliable.

The issue of measurement problem of zero leverage is overcome through restriction of leverage measure to financial debt only. The explanatory variables have been scaled to either an income statement item or total or net assets to ensure they are decimal or percentage magnitude. There may however be few exceptions such as the ratio of market value to book assets of the firm (GROW), firm size measured as the natural logarithm of sales, liquidity measured as the acid-test or quick ratio (QUICK) and firm age measured as the natural logarithm of age since incorporation. Omission of variables may be a concern as only firm-level covariates are considered. However, the firm-level variables are adequate to address the key objective of uncovering the attributes of firms that are zero-levered. The familiar augmented Dickey-Fuller (ADF) and Phillips Perron (PP) tests for the presence of unit roots in the variables show satisfactory result, that is, the variables are stationary at level and first difference I(1).

Because of space constraints, all the explanatory variables are defined in Table 3 . The expected signs of the regression parameters ( $\beta$ 's) are, as stated in column 5 of Table 3 . The expected signs and magnitude may thus be seen as the underlying hypotheses of the study with potential implications for competing theories of capital structure.

\subsection{Definition of Explanatory Variables}

Table 3. Determinants of Capital Structure and their Expected Signs and Magnitudes

\begin{tabular}{|c|c|c|c|c|c|}
\hline $\mathbf{S} / \mathbf{N}$ & $\begin{array}{l}\text { EXPLANA } \\
\text { TORY } \\
\text { VARIABL E }\end{array}$ & DEFINITION & INDICATION & $\begin{array}{c}\text { EXPEC } \\
\text { TED } \\
\text { SIGN }\end{array}$ & $\begin{array}{c}\text { EXPECTED } \\
\text { MAGNITUDE }\end{array}$ \\
\hline 1 & MTR & $\begin{array}{c}\text { Marginal tax rate, Tax expense } \\
\text { divided by Earnings before tax as in } \\
\text { Barakat and Rao (2013). }\end{array}$ & Effect of the debt tax shield & + & $0<\beta$ MTR $<1$ \\
\hline 2 & NDTS & $\begin{array}{l}\text { Non-debt tax shield, following } \\
\text { DeAngelo and Masulis (1980), } \\
\text { (Depreciation+ Investment tax } \\
\text { credit)/ Total assets less current } \\
\text { liabilities }\end{array}$ & $\begin{array}{l}\text { Substitute for the debt tax } \\
\text { shield }\end{array}$ & - & $-1<\beta$ NDTS $<0$ \\
\hline
\end{tabular}




\begin{tabular}{|c|c|c|c|c|c|}
\hline 3 & TANG & $\begin{array}{l}\text { Tangible assets defined as PPE } \\
\text { divided by total assets less current } \\
\text { liabilities. }\end{array}$ & $\begin{array}{l}\text { Collateral, a measure of debt } \\
\text { capacity. }\end{array}$ & $+/-$ & $-1<\beta$ TANG $<1$ \\
\hline 4 & GROWTH & $\begin{array}{c}\text { Growth opportunities, measured } \\
\text { by the ratio of market-to-book value } \\
\text { of the firm or market to book value } \\
\text { of equity. }\end{array}$ & Growth & - & $-1<\beta$ GROW $<0$ \\
\hline 5 & SIZE & $\begin{array}{l}\text { Size defined as the natural } \\
\text { logarithm of Sales (LNS) }\end{array}$ & Size effect & + & $0<\beta$ SIZE $<\infty$ \\
\hline 6 & VOL & $\begin{array}{c}\text { The volatility of earnings defined as } \\
\text { the standard deviation of EBIT } \\
\text { scaled by Total Assets less current } \\
\text { liabilities }\end{array}$ & Business Risk & - & $-1<\beta \mathrm{VOL}<0$ \\
\hline 7 & PROF & \begin{tabular}{|c|} 
Defined by ROCE or ROA $=$ \\
Earnings before Interest and Taxes/ \\
Total Assets less current liabilities
\end{tabular} & Profitability & $+/-$ & $-1<\beta \mathrm{PROF} \leq 1$ \\
\hline 8 & QUICK & $\begin{array}{c}\text { A stricter measure of liquidity } \\
\text { relative to the current ratio. The } \\
\text { quick ratio is the Current assets less } \\
\text { inventory divided by current } \\
\text { liabilities }\end{array}$ & Liquidity & $+/-$ & $-1<\beta Q \mathrm{QUICK} \leq 1$ \\
\hline 9 & R\&D & $\begin{array}{l}\text { Research \& Development plus } \\
\text { other intangible assets / (Total } \\
\text { Assets - Current Liabilities) }\end{array}$ & $\begin{array}{lcc}\text { Asset } & \begin{array}{c}\text { Uniqueness } \\
\text { intangibility }\end{array} & \text { or }\end{array}$ & - & $-1<\beta \mathrm{RD}<0$ \\
\hline 10 & $\mathrm{DEF}$ & $\begin{array}{l}\text { Financing deficit = change in total } \\
\text { assets+ dividends - profit after tax } \\
\text { OR net decrease in cash and cash } \\
\text { equivalents scaled by (Total assets } \\
\text { less current liabilities). }\end{array}$ & $\begin{array}{c}\text { Adverse selection in external } \\
\text { Financing (Lambrecht \& } \\
\text { Myers, 2017). }\end{array}$ & + & $\begin{array}{c}0<\beta \mathrm{DEF} \leq 1 \\
\mathrm{OR} \\
\beta \mathrm{DEF}=\beta \mathrm{PO}=1\end{array}$ \\
\hline \multirow[t]{2}{*}{11} & DIV & \begin{tabular}{|} 
Dividend payout ratio defined as \\
Dividends divided by Profit after tax \\
(PAT) \\
or \\
Dividend per share (DPS) divided \\
by earnings per share (EPS).
\end{tabular} & \begin{tabular}{|c|} 
1) Asymmetric \\
information. Low payout firms \\
will prefer debt over equity \\
financing.
\end{tabular} & - & $-1<\beta$ DIV $<0$ \\
\hline & & $\begin{array}{c}\text { This variable was engaged in } \\
\text { Barakat and Rao (2013) }\end{array}$ & \begin{tabular}{|c|} 
2) Effect of personal \\
taxes - the relative advantage of \\
dividends to interest income.
\end{tabular} & & \\
\hline 12 & RAT & $\begin{array}{c}\text { Rating dummy as a proxy for debt } \\
\text { market access; one if the firm is } \\
\text { rated and zero if the firm is unrated }\end{array}$ & $\begin{array}{c}\text { Rated firms are assumed to be } \\
\text { more highly levered than their } \\
\text { unrated counterparts. }\end{array}$ & + & $0<\beta$ RAT $<1$ \\
\hline 13 & $\mathrm{AGE}$ & $\begin{array}{c}\text { Ln (Number of years since } \\
\text { incorporation). }\end{array}$ & $\begin{array}{l}\text { Impact of the firm's age on } \\
\text { financing decisions. AGE } \\
\text { correlates with SIZE. }\end{array}$ & + & $0<\beta \mathrm{AGE}<1$ \\
\hline
\end{tabular}




\begin{tabular}{|c|c|c|c|c|c|}
\hline 14 & (Dit* - Dit-1) & $\begin{array}{c}\text { Target adjustment in debt ratios, } \\
\text { measured as target debt ratio minus } \\
\text { lagged debt ratio. Target debt ratio } \\
\text { can be proxied by historical average } \\
\text { or industry median leverage where } \\
\text { available. }\end{array}$ & $\begin{array}{c}\text { Target behavior in financing. } \\
\beta \mathrm{TA}>0-\text { target behavior holds } \\
\beta \mathrm{TA}<1-+ \text { ve adjustment costs. } \\
\text { Chang \& Dasgupta (2009). }\end{array}$ & + & $0<\beta \mathrm{TA}<1$ \\
\hline 15 & UNQ & $\begin{array}{l}\text { Uniqueness dummy (for distress } \\
\text { risk) that takes the value of one for } \\
\text { firms producing computers, } \\
\text { semiconductors, chemicals and } \\
\text { allied, aircraft, space vehicles, and } \\
\text { other sensitive industries, and zero } \\
\text { otherwise. }\end{array}$ & $\begin{array}{c}\text { Asset uniqueness/ Industry } \\
\text { uniqueness. }\end{array}$ & - & $-1<\beta \mathrm{UNQ}<0$ \\
\hline
\end{tabular}

Source: Paseda (2016)

\section{Empirical Results}

This section presents the empirical analysis and results of the study. Again, the research aims to investigate the forces driving zero-leverage behaviour in the capital structure decisions of Nigerian quoted firms. The description of the variables begins from the summary statistics contained in Table 4. The regression results are shown in Tables 4 to 10.

Table 4. Summary Statistics for Zero-Leverage Firms in the Study

\begin{tabular}{|c|c|c|c|c|c|c|c|c|c|c|c|c|c|}
\hline & ML1T & MTR & NDTS & TANG & GROW & SIZE & VOL & PROF & QUICK & RD & DIV & AGE & RAT \\
\hline Mean & 0.014 & 0.292 & 0.118 & 0.590 & 5.854 & 16.145 & 0.155 & 0.376 & 0.793 & 0.024 & 0.568 & 3.750 & 0.062 \\
\hline Median & 0.004 & 0.320 & 0.077 & 0.563 & 4.540 & 16.253 & 0.122 & 0.355 & 0.719 & 0.000 & 0.579 & 3.761 & 0.000 \\
\hline Maximum & 0.050 & 0.748 & 0.776 & 1.000 & 13.238 & 19.409 & 0.754 & 0.792 & 2.483 & 0.739 & 1.000 & 4.500 & 1.000 \\
\hline Minimum & 0.000 & -0.402 & 0.021 & 0.105 & -0.961 & 12.460 & 0.030 & -0.298 & 0.163 & 0.000 & 0.000 & 2.996 & 0.000 \\
\hline Std. Dev. & 0.017 & 0.134 & 0.135 & 0.297 & 4.665 & 1.742 & 0.131 & 0.240 & 0.380 & 0.092 & 0.301 & 0.306 & 0.242 \\
\hline Skewness & 0.782 & -1.257 & 2.930 & 0.013 & 0.414 & -0.217 & 2.532 & 0.096 & 1.382 & 6.089 & -0.342 & -0.100 & 3.625 \\
\hline Kurtosis & 2.088 & 9.528 & 11.425 & 1.724 & 1.685 & 2.059 & 10.567 & 2.738 & 6.342 & 43.300 & 2.309 & 2.944 & 14.143 \\
\hline Jarque-Bera & 28.524 & 426.216 & 917.192 & 14.192 & 21.034 & 9.341 & 721.898 & 0.918 & 163.779 & 15434.71 & 8.236 & 0.379 & 1539.2 \\
\hline Probability & 0.000 & 0.000 & 0.000 & 0.001 & 0.000 & 0.009 & 0.000 & 0.632 & 0.000 & 0.000 & 0.016 & 0.828 & 0.000 \\
\hline Sum & 2.903 & 61.043 & 24.607 & 123.2 & 1223.6 & 3374.3 & 32.5 & 78.5 & 165.6 & 5.0 & 118.8 & 783.8 & 13.0 \\
\hline $\begin{array}{l}\text { Sum Sq. } \\
\text { Dev. }\end{array}$ & 0.059 & 3.715 & 3.769 & 18.377 & 4526.08 & 631.03 & 3.571 & 11.996 & 30.064 & 1.766 & 18.899 & 19.537 & 12.191 \\
\hline Observations & 209 & 209 & 209 & 209 & 209 & 209 & 209 & 209 & 209 & 209 & 209 & 209 & 209 \\
\hline
\end{tabular}

Source: Underlying results from the analysis of financial statements and market data

The dependent variable is the market leverage ratio I (ML1), which captures financial liabilities only, defined as the ratio of financial liabilities to the sum of financial liabilities and equity, using market values. 
The explanatory variables are marginal tax rate (MTR), non-debt tax shields (NDTS), the tangibility of assets (TANG), growth opportunities (GROW), size of the firm (SIZE), the volatility of earnings before interest and taxes (VOL). Firm profitability (PROF), liquidity measured by the quick or acid-test ratio (QUICK), assets' riskiness measured by research and developments and other intangible assets (RD), dividend payout ratio (DIV), age of the firm (AGE), rating dummy as a proxy for debt market access (RAT) as defined in Table 3. All variables capture firm-specific attributes. Most of the variables with outlier presence became winsorized at the 5th and 95th percentiles corresponding to lower and upper values, respectively.

Firm characteristics are ranked in Table 5 as follows in terms of their mean values, namely: Size, growth opportunities, age, liquidity as measured by acid-test or quick ratio, asset solidity, dividend payout policy (in terms of high versus low payout). Profitability, marginal tax rate, earnings volatility, non-debt tax shield, debt market access measured by rating dummy, and Research and Development (R\&D) are the other firm characteristics. Among the firm factors, the R\&D showed the least dispersion around the mean, as can be observed from its standard deviation.

Table 5. Correlation Matrix of Variables Used in the Study

\begin{tabular}{|c|c|c|c|c|c|c|c|c|c|c|c|c|c|}
\hline & ML1T & MTR & NDTS & TANG & GROW & SIZE & VOL & PROF & QUICK & $\mathrm{RD}$ & DIV & AGE & RAT \\
\hline ML1T & 1.000 & 0.027 & 0.026 & 0.295 & 0.095 & 0.148 & $\begin{array}{l}- \\
0.113\end{array}$ & 0.110 & -0.236 & 0.030 & 0.101 & 0.256 & 0.164 \\
\hline MTR & -0.027 & 1.000 & 0.080 & 0.155 & 0.129 & 0.014 & 0.062 & 0.054 & -0.134 & $\begin{array}{l}- \\
0.011\end{array}$ & $\begin{array}{l}- \\
0.119\end{array}$ & 0.002 & $\begin{array}{l}- \\
0.018\end{array}$ \\
\hline NDTS & 0.026 & 0.080 & 1.000 & 0.152 & -0.096 & $\begin{array}{l}- \\
0.085\end{array}$ & $\begin{array}{l}- \\
0.015\end{array}$ & 0.149 & -0.155 & $\begin{array}{l}- \\
0.003\end{array}$ & $\overline{-}-\overline{0} 8$ & $\overline{-}-140$ & 0.207 \\
\hline TANG & 0.295 & 0.155 & 0.152 & 1.000 & 0.252 & 0.457 & 0.052 & 0.085 & -0.474 & 0.247 & 0.145 & 0.264 & 0.067 \\
\hline GROW & 0.095 & 0.129 & -0.096 & 0.252 & 1.000 & 0.492 & 0.343 & 0.543 & -0.205 & 0.200 & 0.398 & 0.410 & 0.063 \\
\hline SIZE & 0.148 & 0.014 & -0.085 & 0.457 & 0.492 & 1.000 & 0.005 & 0.409 & -0.182 & 0.243 & 0.329 & 0.712 & 0.243 \\
\hline VOL & -0.113 & $\overline{-}-0.062$ & -0.015 & -0.052 & 0.343 & 0.005 & 1.000 & 0.245 & -0.017 & 0.030 & 0.008 & 0.126 & $\begin{array}{l}- \\
0.061\end{array}$ \\
\hline PROF & -0.110 & $\begin{array}{l}- \\
0.054\end{array}$ & 0.149 & 0.085 & 0.543 & 0.409 & 0.245 & 1.000 & -0.082 & 0.155 & 0.417 & 0.256 & 0.028 \\
\hline QUICK & -0.236 & $\begin{array}{l}- \\
0.134\end{array}$ & -0.155 & -0.474 & -0.205 & $\begin{array}{l}- \\
0.182\end{array}$ & $\begin{array}{l}- \\
0.017\end{array}$ & $\begin{array}{l}- \\
0.082\end{array}$ & 1.000 & $\begin{array}{l}- \\
0.160\end{array}$ & $\begin{array}{l}- \\
0.025\end{array}$ & $\begin{array}{l}- \\
0.194\end{array}$ & 0.031 \\
\hline $\mathrm{RD}$ & 0.030 & $\begin{array}{l}- \\
0.011\end{array}$ & -0.003 & 0.247 & 0.200 & 0.243 & 0.030 & 0.155 & -0.160 & 1.000 & 0.134 & 0.256 & $\begin{array}{l} \\
0.019\end{array}$ \\
\hline DIV & 0.101 & $\begin{array}{l}- \\
0.119\end{array}$ & -0.058 & 0.145 & 0.398 & 0.329 & 0.008 & 0.417 & -0.025 & 0.134 & 1.000 & 0.199 & 0.040 \\
\hline AGE & 0.256 & 0.002 & -0.140 & 0.264 & 0.410 & 0.712 & 0.126 & 0.256 & -0.194 & 0.256 & 0.199 & 1.000 & 0.221 \\
\hline RAT & 0.164 & $\begin{array}{l}- \\
0.018\end{array}$ & 0.207 & 0.067 & -0.063 & 0.243 & $\begin{array}{l}- \\
0.061\end{array}$ & 0.028 & 0.031 & $\begin{array}{l}- \\
0.019\end{array}$ & 0.040 & 0.221 & 1.000 \\
\hline
\end{tabular}

Source: Authors' analysis 
The dependent variable is the market leverage ratio I (ML1), which captures financial liabilities only, defined as the ratio of financial liabilities to the sum of financial liabilities and equity, using market values. The explanatory variables consist of the marginal tax rate (MTR), non-debt tax shields (NDTS), the tangibility of assets (TANG), growth opportunities (GROW), size of the firm (SIZE), the volatility of earnings before interest and taxes (VOL), firm profitability (PROF). Others are liquidity measured by quick or an acid-test ratio (QUICK), assets' riskiness measured by research and developments and other intangible assets (RD), dividend payout ratio (DIV), age of the firm (AGE). Moreover, the rating dummy as a proxy for debt market access (RAT) is as defined in Table 3. All variables capture firm-specific attributes. In resolving the issue of outliers, most of the variables with outlier presence became winsorized at the 5th and 95th percentiles corresponding to lower and upper values, respectively.

The correlation matrix gives the first assurance that the explanatory variables are not highly correlated so that multicollinearity is not a concern. Except for size and age with a correlation coefficient of $71 \%$, which is unsurprising as older firms tend to be bigger, all other variables are only moderately associated.

Table 6. Zero Leverage Regressions Designed to Uncover Zero-Levered Firms Attributes

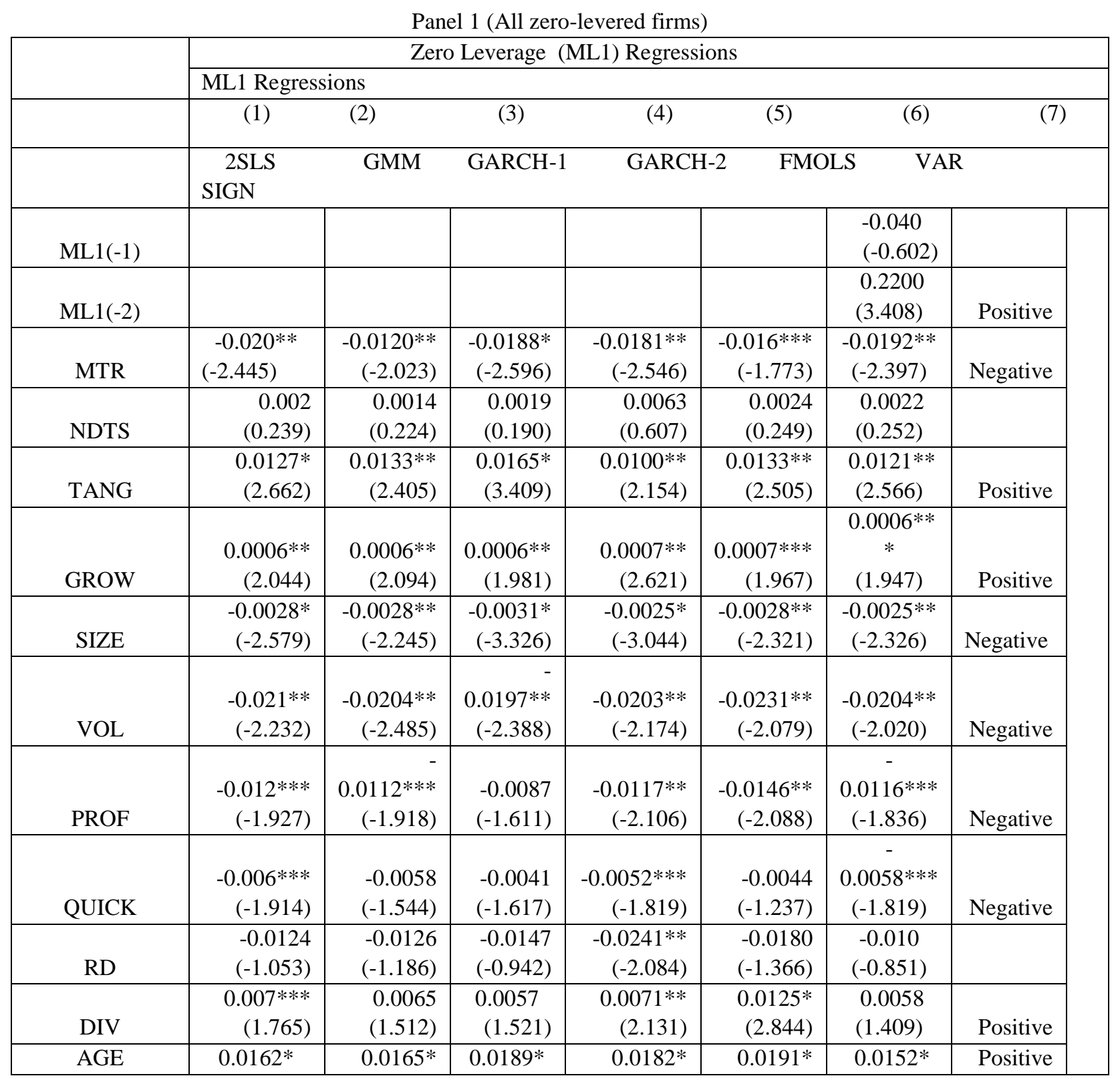




\begin{tabular}{|c|c|c|c|c|c|c|c|}
\hline & $(3.897)$ & $(3.374)$ & $(32.972)$ & $(6.002)$ & (3.338) & (2.886) & \\
\hline RAT & $\begin{array}{l}0.0101 * * \\
\quad(2.267)\end{array}$ & $\begin{array}{r}0.0101 * * \\
(2.341)\end{array}$ & $\begin{array}{c}0.0092 \\
(1.611)\end{array}$ & $\begin{array}{r}0.0053 \\
(1.033)\end{array}$ & $\begin{array}{r}0.0099 * * * \\
(1.892)\end{array}$ & $\begin{array}{c}0.0089 * * \\
* \\
(1.913)\end{array}$ & Positive \\
\hline Adjusted $\mathrm{R}^{2}$ & 0.2043 & 0.2040 & 0.1955 & 0.2079 & 0.190 & 0.2421 & \\
\hline Durbin-Watson & 2.0654 & 2.0575 & 2.0548 & 1.9670 & 2.0548 & & \\
\hline Observations & 209 & 209 & 209 & 209 & 209 & 209 & \\
\hline
\end{tabular}

Notes: * indicates significance at $1 \%, * *$ indicates significance at 5\%, and *** indicates significance at $10 \%$

The dependent variable is the market leverage ratio I (ML1), which captures financial liabilities only, defined as the ratio of financial liabilities to the sum of financial liabilities and equity, using market values. The explanatory variables are marginal tax rate (MTR), non-debt tax shields (NDTS), the tangibility of assets (TANG), growth opportunities (GROW), size of the firm (SIZE), the volatility of earnings before interest and taxes (VOL), firm profitability (PROF). Others are liquidity measured by quick or an acid-test ratio (QUICK), assets' riskiness measured by research and developments and other intangible assets (RD), dividend payout ratio (DIV), age of the firm (AGE). However, the rating dummy as a proxy for debt market access (RAT) is as defined in Table 3. Reported are Coefficients, t-statistics (in parentheses), and statistical significance. Adjusted are standard errors for heteroscedasticity and clustering at the firm level. All variables capture firm-specific attributes. In resolving the issue of outliers, most of the variables with outlier presence became winsorized at the 5th and 95th percentiles corresponding to lower and upper values, respectively.

From the above results in Table 6, zero-debt (and almost zero-debt) policy is a declining function of the marginal tax rate, the volatility of earnings, profitability, and liquidity. Factors that exert positive influences on zero-debt use are asset tangibility, growth opportunities, dividend payout policy, age, and debt market access. In other words, firms that implement zero- (and almost zero-) leverage policy have higher tangible assets, higher growth opportunities, pay higher dividends, are older, and have higher debt market access. Out of the 17 sectors covered in this study, 13 displayed the zero-leverage phenomenon. There is a concentration of zero levered firms in the following sectors, namely: Breweries, food and beverages, publishing, health care, chemical and paints, oil and gas, aviation/airline, agriculture, building materials, computers, conglomerate, construction and engineering. The significant market leverage lag to the order of 2 in the vector autoregression estimates is indicative of the fertility of dynamic panel models to the analysis of the zero leverage phenomenon. Indeed prior work documents evidence in support of both capital structure stability and capital structure adjustments until the debate around this took a new turn toward examining the speed of adjustment of capital structures (Fama \& French, 2002; Lemmon, Roberts \& Zender, 2008; Lemmon \& Zender, 2010; DeAngelo \& Roll, 2015).

Further analysis of this zero-leverage behaviour along with the profitability, liquidity, and dividend-paying status of these firms follow below.

Table 7. Determinants of Zero-Leverage Behaviour of Profitable Firms

Panel 2 - Profitable Zero-levered Firms

Profitable Zero Levered Firms Regressions Designed to Uncover Firms Attributes

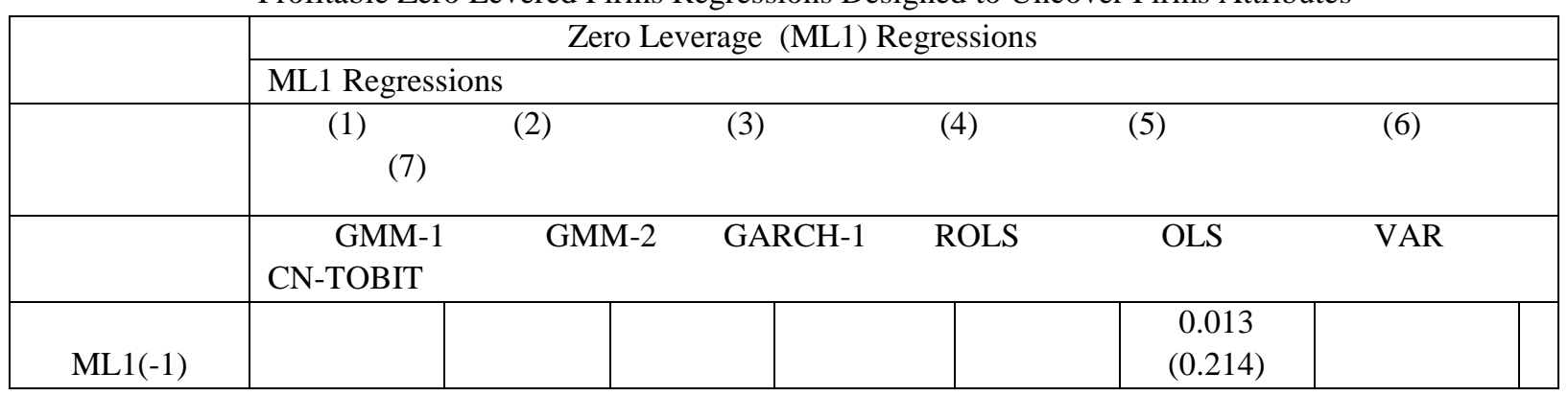




\begin{tabular}{|c|c|c|c|c|c|c|c|}
\hline $\operatorname{ML1}(-2)$ & & & & & & $\begin{array}{c}-0.008 \\
(-0.193)\end{array}$ & \\
\hline MTR & $\begin{array}{l}-0.040 * \\
(-3.726)\end{array}$ & $\begin{array}{l}-0.040 * \\
(-3.768)\end{array}$ & $\begin{array}{r}-0.040 * * \\
(-2.372)\end{array}$ & $\begin{array}{l}-0.040^{*} \\
(-2.729)\end{array}$ & $\begin{array}{l}-0.040 * \\
(-2.880)\end{array}$ & $\begin{array}{c}-0.0378^{*} \\
(-2.667)\end{array}$ & $\begin{array}{c}-0.073 * \\
(-3.239)\end{array}$ \\
\hline NDTS & & $\begin{array}{r}0.007 \\
(0.939)\end{array}$ & $\begin{array}{r}0.006 \\
(0.532)\end{array}$ & $\begin{array}{r}0.009 \\
(1.001)\end{array}$ & $\begin{array}{r}0.006 \\
(0.723)\end{array}$ & $\begin{array}{c}0.0096 \\
(1.034)\end{array}$ & $\begin{array}{r}0.004 \\
(0.338)\end{array}$ \\
\hline TANG & & $\begin{array}{r}0.008 \\
(1.471) \\
\end{array}$ & $\begin{array}{r}0.008 \\
(1.323) \\
\end{array}$ & $\begin{array}{r}0.010 * * * \\
(1.662)\end{array}$ & $\begin{array}{r}0.008 \\
(1.456) \\
\end{array}$ & $\begin{array}{c}0.009 \\
(1.504) \\
\end{array}$ & $\begin{array}{r}0.021 * * \\
(2.424)\end{array}$ \\
\hline GROW & $\begin{array}{r}0.001 * * \\
(2.093)\end{array}$ & $\begin{array}{r}0.001 * * * \\
(1.798)\end{array}$ & $\begin{array}{r}0.001 * * * \\
(1.787)\end{array}$ & $\begin{array}{r}0.001 * * \\
(2.445)\end{array}$ & $\begin{array}{r}0.001 * * \\
(1.912)\end{array}$ & $\begin{array}{c}0.001 * * * \\
(1.760)\end{array}$ & $\begin{array}{r}0.001 * * * \\
(1.666)\end{array}$ \\
\hline SIZE & & $\begin{array}{r}-0.001 \\
(-0.815)\end{array}$ & $\begin{array}{r}-0.001 \\
(-0.767)\end{array}$ & $\begin{array}{r}-0.002 \\
(-1.527)\end{array}$ & $\begin{array}{r}-0.001 \\
(-0.813)\end{array}$ & $\begin{array}{c}-0.001 \\
(-0.721)\end{array}$ & $\begin{array}{r}-0.001 \\
(-0.749)\end{array}$ \\
\hline VOL & & $\begin{array}{r}-0.011 \\
(-1.153)\end{array}$ & $\begin{array}{r}-0.011 \\
(-0.584)\end{array}$ & $\begin{array}{r}-0.010 \\
(-0.655)\end{array}$ & $\begin{array}{r}-0.012 \\
(-0.849)\end{array}$ & $\begin{array}{c}-0.011 \\
(-0.810)\end{array}$ & $\begin{array}{r}-0.020 \\
(-0.912)\end{array}$ \\
\hline PROF & $\begin{array}{l}-0.031 * \\
(-4.345)\end{array}$ & $\begin{array}{l}-0.027 * \\
(-3.433)\end{array}$ & $\begin{array}{r}-0.027 * * \\
(-2.163)\end{array}$ & $\begin{array}{l}-0.028 * \\
(-2.810)\end{array}$ & $\begin{array}{r}-0.0263 * \\
(-2.835)\end{array}$ & $\begin{array}{l}-0.027 * \\
(-2.829)\end{array}$ & $\begin{array}{r}-0.037 * * \\
(-2.503)\end{array}$ \\
\hline QUICK & & $\begin{array}{r}-0.004 \\
(-1.060)\end{array}$ & $\begin{array}{r}-0.005 \\
(-1.122)\end{array}$ & $\begin{array}{r}-0.006 \\
(-1.220)\end{array}$ & $\begin{array}{r}-0.005 \\
(-1.093)\end{array}$ & $\begin{array}{c}-0.003 \\
(-0.665)\end{array}$ & $\begin{array}{r}-0.005 \\
(-0.821)\end{array}$ \\
\hline $\mathrm{RD}$ & & $\begin{array}{r}-0.006 \\
(-0.593) \\
\end{array}$ & $\begin{array}{r}-0.010 \\
(-0.877) \\
\end{array}$ & $\begin{array}{r}-0.008 \\
(-0.649) \\
\end{array}$ & $\begin{array}{r}-0.009 \\
(-0.763) \\
\end{array}$ & $\begin{array}{c}-0.010 \\
(-0.813) \\
\end{array}$ & $\begin{array}{r}-0.014 \\
(-0.800) \\
\end{array}$ \\
\hline DIV & $\begin{array}{r}0.007 \\
(1.446)\end{array}$ & $\begin{array}{r}0.008 \\
(1.521)\end{array}$ & $\begin{array}{r}0.009 \\
(1.522)\end{array}$ & $\begin{array}{r}0.006 \\
(1.218)\end{array}$ & $\begin{array}{r}0.008 * * * \\
(1.664)\end{array}$ & $\begin{array}{c}0.008 \\
(1.585)\end{array}$ & $\begin{array}{r}0.014 * * * \\
(1.675)\end{array}$ \\
\hline AGE & $\begin{array}{c}0.008 * \\
(8.066)\end{array}$ & $\begin{array}{r}0.012 * * \\
(2.257)\end{array}$ & $\begin{array}{c}0.012 * * \\
(2.351)\end{array}$ & $\begin{array}{c}0.016 * \\
(3.052)\end{array}$ & $\begin{array}{c}0.012 * * \\
(2.451)\end{array}$ & $\begin{array}{c}0.0135 * * \\
(2.292)\end{array}$ & $\begin{array}{r}0.013 * * * \\
(1.781)\end{array}$ \\
\hline RAT & $\begin{array}{r}0.007 * * \\
(2.033)\end{array}$ & $\begin{array}{r}0.007 * * * \\
(1.842)\end{array}$ & $\begin{array}{r}0.007 \\
(1.347)\end{array}$ & $\begin{array}{r}0.009 * * * \\
(1.853)\end{array}$ & $\begin{array}{r}0.007 \\
(1.527)\end{array}$ & $\begin{array}{r}0.0074 \\
(1.444)\end{array}$ & $\begin{array}{r}0.013 * * \\
(2.017)\end{array}$ \\
\hline Adjusted $\mathrm{R}^{2}$ & 0.1831 & 0.2069 & 0.2076 & 0.1937 & 0.190 & 0.272 & \\
\hline $\begin{array}{l}\text { Durbin- } \\
\text { Watson }\end{array}$ & 2.0199 & 2.0222 & 2.0205 & & 2.0548 & & \\
\hline Observations & 156 & 156 & 156 & 156 & 156 & 156 & \\
\hline
\end{tabular}

Notes: * indicates significance at $1 \%, * *$ indicates significance at 5\%, and *** indicates significance at $10 \%$

Captured here are zero-leveraged firms with return on capital employed higher than or equal to $20 \%$. The observations are reduced from 209 to 156 , representing a $25 \%$ decline. The dependent variable is the market leverage ratio I (ML1), which captures financial liabilities only, defined as the ratio of financial liabilities to the sum of financial liabilities and equity, using market values. The explanatory variables are marginal tax rate (MTR), non-debt tax shields (NDTS), the tangibility of assets (TANG), growth opportunities (GROW), size of the firm (SIZE), the volatility of earnings before interest and taxes (VOL), firm profitability (PROF). Others are liquidity measured by quick or an acid-test ratio (QUICK), assets' riskiness measured by research and developments and other intangible assets (RD), dividend payout ratio (DIV), age of the firm (AGE). However, the rating dummy as a proxy for debt market access (RAT) is as defined in Table 3. Reported are the coefficients, t-statistics (in parentheses), and statistical significance. Adjusted are standard errors for heteroscedasticity and clustering at the firm level. All variables capture firm-specific attributes. In resolving the issue of outliers, most of the variables with outlier presence became winsorized at the 5th and 95th percentiles corresponding to lower and upper values, respectively. The estimation techniques include a generalized method of moments (GMM), and the generalized autoregressive conditional heteroscedasticity (GARCH). Others are the Robust least squares (RoLS), Ordinary least squares (OLS), Vector Autoregression (VAR), and Censored Normal TOBIT (CN-TOBIT).

Zero-debt (and almost zero-debt) usage is a declining function of the marginal tax rate (MTR), and profitability (PROF). However, it is an increasing function of asset tangibility (TANG), growth opportunities (GROW), firm age (AGE), debt access (RAT), and dividend payout ratio (DIV). Non-debt tax shields fail to 
account for zero-leverage behaviour. Firm size, earnings volatility, liquidity, and asset riskiness also lack explanatory power for the "profitable zero-leverage" phenomenon.

Firms that follow zero-leverage (and almost zero-leverage) policy pay lower taxes, have higher growth opportunities, have more tangible assets, pay higher dividends, are older, and have higher access to debt markets. The profitable zero-levered firms seem to provide a picture of the opinion by Graham (2000) that there is underleveraging many profitable firms. The profitable zero-levered firm's concentration is in the following sectors, namely: food and beverages, breweries, aviation/airline, oil and gas, and healthcare sectors. Table 7 Panel 2 shows the results.

When the sample captures only firm-years with acid test ratios that exceed one to signify abundant liquidity, zero-leverage firm behavior diverges from earlier results for profitable zero-leverage firms along with the following attributes namely: asset tangibility, size, earnings volatility, assets riskiness, dividend payout, age, and debt market access. In words, highly liquid firms that eschew debt pay lower taxes, have more non-debt tax shelters, are more prominent, have more risky assets, and are younger. There is an inverse relationship between conservative capital structure and profitability as well as between conservative debt usage and dividend payout policy. Table 8 Panel 3 shows the results.

Table 8. Determinants of Zero-Leverage Behaviour of Highly Liquid Firms

Panel 3 - Liquid Zero-levered Firms

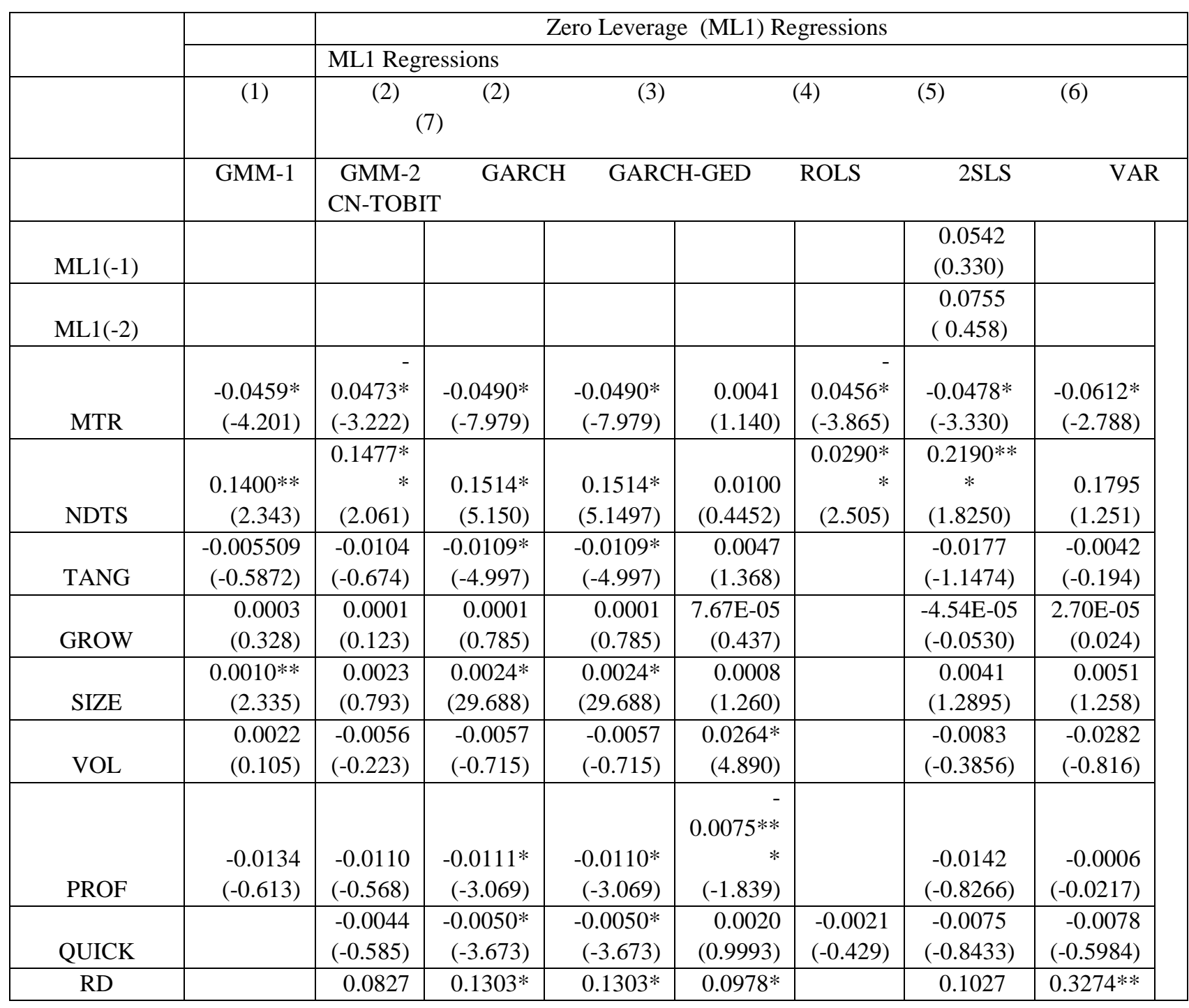




\begin{tabular}{|c|c|c|c|c|c|c|c|c|}
\hline & & $(1.239)$ & $(3.686)$ & $(3.686)$ & (3.913) & & $(0.9698)$ & $(2.0693)$ \\
\hline DIV & & $\begin{array}{l}-0.0041 \\
(-0.642)\end{array}$ & $\begin{array}{r}0.0055^{* *} \\
(-2.165)\end{array}$ & $\begin{array}{r}-0.0055 * * \\
(-2.165)\end{array}$ & $\begin{array}{r}0.0008 \\
(0.4374)\end{array}$ & & $\begin{array}{c}-0.0054 \\
(-0.7351)\end{array}$ & $\begin{array}{r}0.0205 * * \\
* \\
(-1.6515)\end{array}$ \\
\hline AGE & & $\begin{array}{l}-0.0026 \\
(-0.252)\end{array}$ & $\begin{array}{r}0.0029 * * \\
(-2.140)\end{array}$ & $\begin{array}{r}-0.0029 * * \\
(-2.1396)\end{array}$ & $\begin{array}{r}-0.0055^{*} \\
(-2.825)\end{array}$ & $\begin{array}{r}0.0055 * \\
* \\
(2.249)\end{array}$ & $\begin{array}{c}-0.0078 \\
(-0.7098)\end{array}$ & $\begin{array}{r}-0.0133 \\
(-1.0849)\end{array}$ \\
\hline RAT & $\begin{array}{r}-0.0552 * * \\
(-1.990) \\
\end{array}$ & $\begin{array}{l}-0.0606 \\
(-1.724) \\
\end{array}$ & $\begin{array}{r}-0.0586^{*} \\
(-3.833) \\
\end{array}$ & $\begin{array}{r}-0.0586^{*} \\
(-3.833) \\
\end{array}$ & $\begin{array}{l}0.0141 \\
(1.198) \\
\end{array}$ & & $\begin{array}{c}-0.0974 \\
(-1.5124)\end{array}$ & $\begin{array}{l}-0.0714 \\
(-0.947)\end{array}$ \\
\hline Adjusted $\mathrm{R}^{2}$ & 0.2803 & 0.2325 & 0.1766 & 0.1766 & & 0.2928 & 0.2087 & \\
\hline $\begin{array}{l}\text { Durbin- } \\
\text { Watson }\end{array}$ & 1.7085 & 1.7085 & 1.5942 & 1.5942 & & 1.7917 & & \\
\hline Observations & 51 & 51 & 51 & 51 & 51 & 51 & 51 & \\
\hline
\end{tabular}

Notes: $*$ indicates significance at $1 \%, * *$ indicates significance at $5 \%$, and $* * *$ indicates significance at $10 \%$

Captured in this panel are the zero-leveraged firms whose acid-test ratios are not less than 1 . The dependent variable is the market leverage ratio I (ML1), which captures financial liabilities only, defined as the ratio of financial liabilities to the sum of financial liabilities and equity, using market values. The explanatory variables are marginal tax rate (MTR), non-debt tax shields (NDTS), the tangibility of assets (TANG), growth opportunities (GROW), size of the firm (SIZE), the volatility of earnings before interest and taxes (VOL), firm profitability (PROF). Others are the liquidity measured by quick or an acid-test ratio (QUICK), assets' riskiness measured by research and developments and other intangible assets (RD), dividend payout ratio (DIV), age of the firm (AGE). However, the rating dummy as a proxy for debt market access (RAT) as defined in Table 3. Reported are the coefficients, t-statistics (in parentheses), and statistical significance. Adjusted are the standard errors for heteroscedasticity and clustering at the firm level. All variables capture firm-specific attributes. In resolving the issue of outliers, most of the variables with outlier presence became winsorized at the 5th and 95th percentiles corresponding to lower and upper values, respectively. The estimation techniques include a generalized method of moments (GMM), generalized autoregressive conditional heteroscedasticity (GARCH), GARCH -Generalized Error Distribution, Robust least squares (RoLS), Two-stage least squares (2SLS), Vector Autoregression (VAR) and Censored Normal TOBIT (CN-TOBIT).

Table 9. Determinants of Zero-Leverage Behaviour of Dividend-Paying Firms

Panel 4 - Dividend-Paying Zero-levered Firms

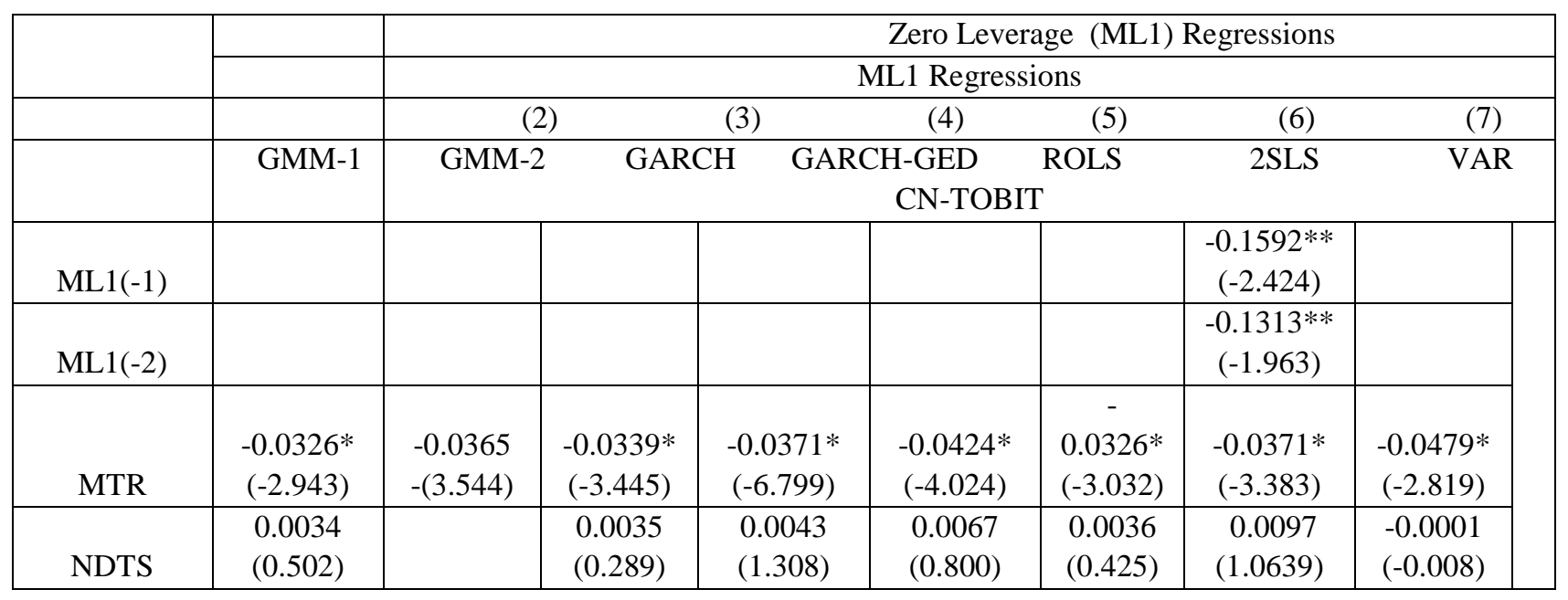




\begin{tabular}{|c|c|c|c|c|c|c|c|c|}
\hline TANG & $\begin{array}{c}0.0085^{* * *} \\
(1.841)\end{array}$ & & $\begin{array}{l}0.0073 \\
(1.309)\end{array}$ & $\begin{array}{c}0.0075^{*} \\
(4.329)\end{array}$ & $\begin{array}{c}0.0088^{* * *} \\
(1.712)\end{array}$ & $\begin{array}{l}0.0084 \\
(1.600)\end{array}$ & $\begin{array}{c}0.0100 * * \\
* \\
(1.895)\end{array}$ & $\begin{array}{c}0.0211 * * \\
(2.527)\end{array}$ \\
\hline GROW & $\begin{array}{c}0.0003 \\
(0.6155)\end{array}$ & & $\begin{array}{l}0.0002 \\
(0.435)\end{array}$ & $\begin{array}{c}7.01 \mathrm{E}-05 \\
(0.880)\end{array}$ & $\begin{array}{c}0.000346 \\
(0.976)\end{array}$ & $\begin{array}{l}0.0003 \\
(0.785)\end{array}$ & $\begin{array}{c}0.0006 \\
(1.550)\end{array}$ & $\begin{array}{l}0.0004 \\
(0.641)\end{array}$ \\
\hline SIZE & $\begin{array}{c}-0.0028 * * \\
(-2.081)\end{array}$ & $\begin{array}{c}0.0019 * * \\
* \\
(-1.895)\end{array}$ & $\begin{array}{c}- \\
0.0028 * * \\
(-2.465)\end{array}$ & $\begin{array}{c}-0.0029 * \\
(-6.030)\end{array}$ & $\begin{array}{c}-0.0047^{*} \\
(-4.112)\end{array}$ & $\begin{array}{c}- \\
0.0028 * \\
* \\
(-2.435)\end{array}$ & $\begin{array}{l}-0.0019 \\
(-1.585)\end{array}$ & $\begin{array}{c}-0.0049 * \\
(-2.694)\end{array}$ \\
\hline VOL & $\begin{array}{l}-0.0095 \\
(-0.887) \\
\end{array}$ & & $\begin{array}{l}-0.0106 \\
(-0.687) \\
\end{array}$ & $\begin{array}{l}0.0017 \\
(0.521) \\
\end{array}$ & $\begin{array}{c}-0.0028 \\
(-0.2040) \\
\end{array}$ & $\begin{array}{l}-0.0094 \\
(-0.683) \\
\end{array}$ & $\begin{array}{l}-0.0067 \\
(-0.475) \\
\end{array}$ & $\begin{array}{l}-0.0171 \\
(-0.765) \\
\end{array}$ \\
\hline PROF & $\begin{array}{c}-0.0162 * * \\
(-2.1998)\end{array}$ & $\begin{array}{c}-0.0188^{*} \\
(-3.448)\end{array}$ & $\begin{array}{l}-0.0154 \\
(-1.620)\end{array}$ & $\begin{array}{c}-0.0163 * \\
(-5.822)\end{array}$ & $\begin{array}{c}- \\
0.018438 * \\
* \\
(-2.276)\end{array}$ & $\begin{array}{c}- \\
0.0164 * \\
* \\
(-1.976)\end{array}$ & $\begin{array}{c}-0.0192 * * \\
(-2.286)\end{array}$ & $\begin{array}{l}-0.0183 \\
(-1.362)\end{array}$ \\
\hline QUICK & $\begin{array}{c}-0.0082 * * \\
(-2.124)\end{array}$ & $\begin{array}{c}-0.0115^{*} \\
(-4.106)\end{array}$ & $\begin{array}{c}- \\
0.0077 * * \\
(-2.323)\end{array}$ & $\begin{array}{c}-0.0093 * \\
(-7.287)\end{array}$ & $\begin{array}{c}-0.0121^{*} \\
(-3.566) \\
\end{array}$ & $\begin{array}{c}- \\
0.0081 * \\
* \\
(-2.339) \\
\end{array}$ & $\begin{array}{c}- \\
0.0068^{* * * *} \\
(-1.805)\end{array}$ & $\begin{array}{l}-0.0090 \\
(-1.627)\end{array}$ \\
\hline $\mathrm{RD}$ & $\begin{array}{l}-0.0089 \\
(-0.873)\end{array}$ & & $\begin{array}{l}-0.0088 \\
(-0.692)\end{array}$ & $\begin{array}{l}-0.0089 \\
(-1.421)\end{array}$ & $\begin{array}{l}-0.00815 \\
(-0.7140)\end{array}$ & $\begin{array}{l}-0.0083 \\
(-0.713)\end{array}$ & $\begin{array}{l}-0.0111 \\
(-0.941)\end{array}$ & $\begin{array}{c}- \\
0.007924 \\
(-0.439)\end{array}$ \\
\hline DIV & $\begin{array}{c}0.0100 * * \\
(2.0786)\end{array}$ & $\begin{array}{c}0.0100 * * \\
(2.163)\end{array}$ & $\begin{array}{c}0.0117 * * \\
(2.171)\end{array}$ & $\begin{array}{c}0.0085^{*} \\
(4.416)\end{array}$ & $\begin{array}{c}0.0112 * * \\
(2.362)\end{array}$ & $\begin{array}{c}0.0097 * \\
* \\
(2.008)\end{array}$ & $\begin{array}{c}0.0103 * * \\
(2.086)\end{array}$ & $\begin{array}{c}0.011484 \\
(1.444)\end{array}$ \\
\hline AGE & $\begin{array}{c}0.0195^{*} \\
(3.484)\end{array}$ & $\begin{array}{c}0.0185^{*} \\
(4.041)\end{array}$ & $\begin{array}{c}0.0194 * \\
(4.232)\end{array}$ & $\begin{array}{c}0.0196 * \\
(9.848)\end{array}$ & $\begin{array}{c}0.0283^{*} \\
(6.127)\end{array}$ & $\begin{array}{c}0.0196 * \\
(4.154)\end{array}$ & $\begin{array}{c}0.0161 * \\
(3.0998)\end{array}$ & $\begin{array}{c}0.0269 * \\
(3.670)\end{array}$ \\
\hline RAT & $\begin{array}{l}0.0126^{*} \\
(3.408) \\
\end{array}$ & $\begin{array}{c}0.0133^{*} \\
(3.019) \\
\end{array}$ & $\begin{array}{c}0.0130^{* * *} \\
(2.194) \\
\end{array}$ & $\begin{array}{l}0.0177^{*} \\
(7.212) \\
\end{array}$ & $\begin{array}{l}0.0164 * \\
(3.708) \\
\end{array}$ & $\begin{array}{l}0.0127^{*} \\
(2.814) \\
\end{array}$ & $\begin{array}{c}0.0092^{* *} \\
(1.927) \\
\end{array}$ & $\begin{array}{c}0.0247^{*} \\
(3.587) \\
\end{array}$ \\
\hline UNQ & $\begin{array}{c}-0.0067 * * \\
(-2.443)\end{array}$ & $\begin{array}{c}-0.0075^{*} \\
(-3.076)\end{array}$ & $\begin{array}{c}-0.0072 * \\
(-2.788)\end{array}$ & $\begin{array}{c}-0.0085^{*} \\
(-8.332)\end{array}$ & $\begin{array}{c}-0.0083^{*} \\
(-3.347)\end{array}$ & $\begin{array}{c}- \\
0.0068^{*} \\
(-2.674)\end{array}$ & & $\begin{array}{c}-0.0144 * \\
(-3.462)\end{array}$ \\
\hline Adjusted R2 & 0.249795 & 0.253970 & 0.247802 & 0.152337 & 0.230646 & $\begin{array}{c}0.24983 \\
0\end{array}$ & 0.252563 & \\
\hline $\begin{array}{l}\text { Durbin- } \\
\text { Watson }\end{array}$ & 2.256758 & 2.263389 & 2.246014 & 2.026244 & & $\begin{array}{c}2.25685 \\
8\end{array}$ & & \\
\hline $\begin{array}{c}\text { Observation } \\
\mathrm{s}\end{array}$ & 188 & 188 & 188 & 188 & 188 & 188 & 188 & 188 \\
\hline
\end{tabular}

Notes: $*$ indicates significance at $1 \%, * *$ indicates significance at 5\%, and *** indicates significance at $10 \%$

Captured in this panel are the zero-leveraged firms whose dividend payout ratios are more significant than zero. The dependent variable is the market leverage ratio I (ML1), which captures financial liabilities only, defined as the ratio of financial liabilities to the sum of financial liabilities and equity, using market values. The explanatory variables are marginal tax rate (MTR), non-debt tax shields (NDTS), the tangibility of assets (TANG), growth opportunities (GROW), size of the firm (SIZE), the volatility of earnings before interest and taxes (VOL), firm profitability (PROF). Others are the liquidity measured by quick or an acid-test ratio (QUICK), assets' riskiness measured by research and developments and other intangible assets (RD), dividend payout ratio (DIV), age of the firm (AGE). However, the rating dummy as a proxy for debt market access (RAT) as defined in Table 3. Reported are the coefficients, t-statistics (in parentheses), and statistical significance. Adjusted are the standard errors for heteroscedasticity and clustering at the firm level. All variables capture firm-specific attributes. To resolve the issue of outliers, most of the variables with outlier presence became winsorized at the 5th and 95th percentiles corresponding to lower and upper values, 
respectively. The estimation techniques include a generalized method of moments (GMM), generalized autoregressive conditional heteroscedasticity (GARCH), GARCH -Generalized Error Distribution, Robust least squares (RoLS), Two-stage least squares (2SLS), Vector Autoregression (VAR) and Censored Normal TOBIT (CN-TOBIT).

Table 10. Determinants of Zero-Leverage Behaviour of No-Dividend-Paying Firms

Panel 5 - No-Dividend Paying Zero-levered Firms

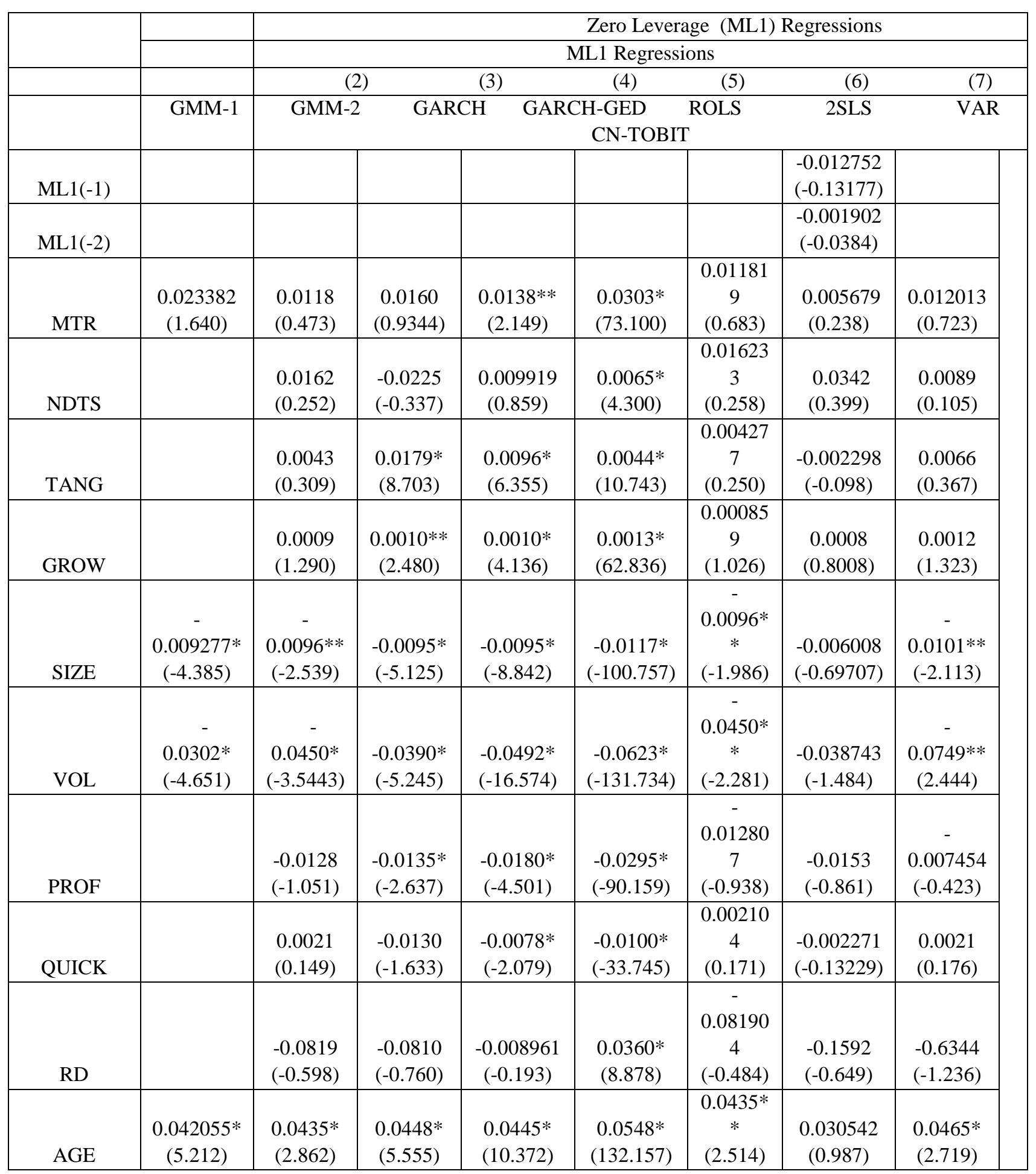




\begin{tabular}{|c|c|c|c|c|c|c|c|c|}
\hline Adjusted R2 & 0.297584 & 0.231972 & & 0.038430 & 0.221482 & 0.23197 & & \\
\hline $\begin{array}{c}\text { Durbin- } \\
\text { Watson }\end{array}$ & 2.155103 & 2.244100 & 2.248467 & 2.454952 & & 2.24410 & & \\
\hline $\begin{array}{c}\text { Observation } \\
\mathrm{s}\end{array}$ & 21 & 21 & 21 & 21 & 21 & 21 & 21 & 21 \\
\hline
\end{tabular}

Notes: * indicates significance at $1 \%, * *$ indicates significance at 5\%, and *** indicates significance at $10 \%$

Captured in this panel are the zero-leveraged firms that do not pay dividends (i.e., dividend payout ratios are zero). Extracted for analysis are firm years with zero dividends. The dependent variable is the market leverage ratio I (ML1), which captures financial liabilities only, defined as the ratio of financial liabilities to the sum of financial liabilities and equity, using market values. The explanatory variables are marginal tax rate (MTR), non-debt tax shields (NDTS), the tangibility of assets (TANG), growth opportunities (GROW), size of the firm (SIZE), the volatility of earnings before interest and taxes (VOL), firm profitability (PROF). Others are the liquidity measured by quick or an acid-test ratio (QUICK), assets' riskiness measured by research and developments and other intangible assets (RD), and age of the firm (AGE) as defined in Table 3. Excluded from the endogenous variables was DIV because of the near singular matrix problem. Reported are the coefficients, t-statistics (in parentheses), and statistical significance. Adjusted are the standard errors for heteroscedasticity and clustering at the firm level. All variables capture firm-specific attributes. In resolving the issue of outliers, most of the variables with outlier presence became winsorized at the 5th and 95th percentiles corresponding to lower and upper values, respectively. The estimation techniques include a generalized method of moments (GMM), generalized autoregressive conditional heteroscedasticity (GARCH), GARCH -Generalized Error Distribution, Robust least squares (RoLS), Two-stage least squares (2SLS), Vector Autoregression (VAR) and Censored Normal TOBIT (CN-TOBIT).

When the panel considers exclusively dividend-paying zero-levered firms (Table IX), then zero-leverage firms are those with more tangible assets, older and have considerable access to the debt market. Dividendpaying zero-levered firms are also those with unique product lines. Similarly, when non-dividend paying firms are studied exclusively the forces that exert influences on zero-leverage behaviour include size, earnings volatility, age and asset tangibility as seen in Table 10. Bigger firms and those with more volatile earnings tend to use debt conservatively.

Besides, the extent of the zero-leverage phenomenon shown, this paper provides another surprising evidence - about theories of capital structure and dividend policy - conventional fact concerning payment of dividend by about $90 \%$ of the firms. This fact poses a challenge for the trade-off theory of capital structure but supports the pecking order. Zero-leverage behavior is highly persistent.

\section{Implications of the Empirical Results}

\subsection{Theoretical Implications}

The signs and magnitude of the coefficients are more consistent with the pecking order theory than the trade-off theory of financing in terms of the number of coefficients tally with theoretical predictions. More specifically, the (negative) signs of the coefficients of profitability, liquidity, tangibility, size, and financing deficit are consistent with the pecking order while the trade-off predicts otherwise. The positive albeit insignificant relationship between leverage and non-debt tax shields is inconsistent with the debt substitution hypothesis of the DeAngelo-Masulis (1980) framework. Instead, the positive relation might be indicative of the assets' collateral value. The availability of alternative tax shelters does not reduce the tax-incentives to borrow. The positive relationships between zero-leverage and tangibility may be indicative of agency problems. In this case, firms having substantial tangible assets which should borrow more, commit to zero debt levels to indulge glamorous managerial lifestyle, fund empire-building projects (over-investment problems), and facilitate excessive consumption of privileges. Relevantly, $24 \%$ of the zero-levered firms are 
highly liquid. The dangers of financial slack and agency costs of equity, as emphasized by Jensen and others, cannot be ignored in these zero-levered firms.

What do the results demonstrate concerning the theoretical determinants of capital structure choice viz-aviz expected costs of financial distress, availability of investment or growth opportunities, managerial entrenchment and private benefits, asset riskiness or intangibility, firm size, asset collateral, information asymmetry between corporate insiders and outside investors, financial flexibility, product market and industry effects (such as industry concentration and product uniqueness), profitability, cash flows and liquidity, and earnings or cash flow volatility? The theoretical pointers are in Table 11 below.

Table 11. Theoretical Implications of the Signs and Magnitudes of the Coefficients of Results

\begin{tabular}{|c|c|c|c|c|c|c|c|}
\hline $\mathrm{S} / \mathrm{N}$ & $\begin{array}{c}\text { Explanatory } \\
\text { Variables }\end{array}$ & $\begin{array}{c}\text { All zero- } \\
\text { levered firms }\end{array}$ & $\begin{array}{l}\text { Profitable } \\
\text { zero-levered } \\
\text { firms }\end{array}$ & $\begin{array}{l}\text { Liquid } \\
\text { zero- } \\
\text { levered } \\
\text { firms }\end{array}$ & $\begin{array}{l}\text { Dividend- } \\
\text { paying } \\
\text { zero- } \\
\text { levered } \\
\text { firms }\end{array}$ & $\begin{array}{l}\text { Non- } \\
\text { Dividend } \\
\text { Payers }\end{array}$ & Indicator/ Implications \\
\hline 1 & $\begin{array}{l}\text { Marginal tax } \\
\text { rate }\end{array}$ & Negative & Negative & Negative & Negative & Positive & $\begin{array}{l}\text { The negative sign indicates } \\
\text { an absence of tax efficiency } \\
\text { in financing decisions. }\end{array}$ \\
\hline 2 & $\begin{array}{l}\text { Non-debt tax } \\
\text { shields }\end{array}$ & & & Positive & & Positive & $\begin{array}{l}\text { Debt complements and } \\
\text { minor collateral value of } \\
\text { assets. Invalidates the } \\
\text { DeAngelo-Masulis' } \\
\text { substitution hypothesis. }\end{array}$ \\
\hline 3 & $\begin{array}{c}\text { Tangible } \\
\text { assets }\end{array}$ & Positive & Positive & Negative & Positive & Positive & $\begin{array}{l}\text { Information asymmetry, } \\
\text { Collateral value of assets. A } \\
\text { positive sign is indicative of } \\
\text { a direct relation between } \\
\text { debt usage and collateral. }\end{array}$ \\
\hline 4 & $\begin{array}{l}\text { Growth } \\
\text { options }\end{array}$ & Positive & Positive & & & Positive & $\begin{array}{l}\text { Conditional on debt } \\
\text { conservatism and in line } \\
\text { with theory. }\end{array}$ \\
\hline 5 & Size & Negative & & Positive & Negative & Negative & $\begin{array}{l}\text { Information asymmetry. } \\
\text { Bankruptcy costs. } \\
\text { Ambiguous depending on } \\
\text { the underlying parameter } \\
\text { driving the interaction. }\end{array}$ \\
\hline 6 & Volatility & Negative & & Positive & & Negative & Business risk \\
\hline 7 & Profitability & Negative & Negative & Negative & Negative & Negative & $\begin{array}{c}\text { More profitable firms } \\
\text { borrow less and vice versa. } \\
\text { Confirms the pecking order } \\
\text { model }\end{array}$ \\
\hline 8 & Liquidity & Negative & & Negative & Negative & Negative & $\begin{array}{l}\text { More liquid firms borrow } \\
\text { less and vice versa. } \\
\text { Financial flexibility is } \\
\text { valuable. Confirms the } \\
\text { pecking order model while } \\
\text { raising the agency problem } \\
\text { of free cash flow }\end{array}$ \\
\hline 9 & $\begin{array}{l}\text { Research and } \\
\text { Development }\end{array}$ & Negative & & Positive & & Positive & $\begin{array}{l}\text { The creation of information } \\
\text { asymmetry and ex-ante } \\
\text { financial distress costs, }\end{array}$ \\
\hline
\end{tabular}




\begin{tabular}{|c|c|c|c|c|c|c|c|}
\hline & & & & & & & $\begin{array}{c}\text { which make firms with } \\
\text { more risky assets borrow } \\
\text { less. }\end{array}$ \\
\hline 10 & $\begin{array}{l}\text { Dividend } \\
\text { payout }\end{array}$ & Positive & Positive & Negative & Positive & & $\begin{array}{l}\text { Information asymmetry, } \\
\text { agency problem. Higher } \\
\text { dividend payouts reduce } \\
\text { agency costs of equity and } \\
\text { information asymmetry }\end{array}$ \\
\hline 11 & Age & Positive & Positive & Negative & Positive & Positive & Older firms borrow more \\
\hline 12 & $\begin{array}{l}\text { Rating (debt } \\
\text { market } \\
\text { access) }\end{array}$ & Positive & Positive & Negative & Positive & & Access to the debt market \\
\hline 13 & $\begin{array}{c}\text { Product } \\
\text { uniqueness }\end{array}$ & & & & Negative & & $\begin{array}{l}\text { Product-specific } \\
\text { requirements, skills, and } \\
\text { capital }\end{array}$ \\
\hline
\end{tabular}

Source: Authors' compilations

Captured in this panel are the zero-leveraged firms that do not pay dividends (i.e., dividend payout ratios are zero). Extracted for analysis are firm years with zero dividends. The dependent variable is the market leverage ratio I (ML1), which captures financial liabilities only, defined as the ratio of financial liabilities to the sum of financial liabilities and equity, using market values. The explanatory variables are marginal tax rate (MTR), non-debt tax shields (NDTS), the tangibility of assets (TANG), growth opportunities (GROW), size of the firm (SIZE), the volatility of earnings before interest and taxes (VOL), firm profitability (PROF). Others are the liquidity measured by quick or an acid-test ratio (QUICK), assets' riskiness measured by research and developments and other intangible assets (RD), and age of the firm (AGE) as defined in Table 3. Excluded from the endogenous variables is the DIV because of the near singular matrix problem. Reported are the coefficients, t-statistics (in parentheses), and statistical significance. Adjusted are the standard errors for heteroscedasticity and clustering at the firm level. All variables capture firm-specific attributes. In resolving the issue of outliers, most of the variables with outlier presence became winsorized at the 5th and 95th percentiles corresponding to lower and upper values, respectively. The estimation techniques include a generalized method of moments (GMM), generalized autoregressive conditional heteroscedasticity (GARCH), GARCH -Generalized Error Distribution, Robust least squares (RoLS), Two-stage least squares (2SLS), Vector Autoregression (VAR) and Censored Normal TOBIT (CN-TOBIT).

\subsection{Practical Implications}

The results of the regression analysis need to be taken with a large grain of salt as capital structure decisions are endogenous to other financial and investment decisions. Nonetheless, the reported correlations in Table 5 are indicative of the association between market leverage and firm attributes. The analysis does not delve into the quantification of the tax benefits which the firms bypass because of their conservative debt usage. These results also clearly indicate managerial risk aversion, which poses to be a more significant agency problem for profitable firms with free cash flow. If the free cash flow is not being distributed to investors as found in roughly $10 \%$ of the firm-year observations, then the corporate managers are destroying value. Competitive managerial market forces both inside and outside these firms may act to control managers faced with temptations to slack or consume excessive perquisites. 


\section{Summary and Conclusion}

This study showcases existing data and panel data regression models to address the gaps related to the questions of why and how firm-specific attributes affect zero leverage behaviour of Nigerian quoted firms. The latter becomes pertinent despite the enormous tax benefits of debts left unexploited and, in many instances, amidst low ex-ante financial distress costs. The coverage of a broad sample of firms across 17 industries out of which 13 industries reveal the persistence of the zero leverage puzzle makes the dataset unique. A combination of factors such as the marginal tax rate, non-debt tax shields, assets tangibility, growth opportunities, size, earnings volatility, profitability, liquidity, dividend, age and debt market access with information on market leverage.

With the empirical results, the study establishes that firms that follow zero-leverage policy pay lower taxes have higher tangible assets, higher growth opportunities, pay higher dividends, are older, and have higher debt market access. Out of the 17 sectors covered in this study, the 13 industries which displayed the zeroleverage phenomenon have firms that are in the 75th percentile of size, age, profitability and marginal tax rate. These results are puzzling given the potential tax-shield benefit maximization loss function assuming the shareholder wealth maximization objective also holds. Could it be that these firms do not have investment opportunities of the scale that warrant external financing as would be the case for the high growth firms or are there labour market effects such as product-specific and unemployment risk concentration? This area calls for further research and analysis. Zero-levered firms' concentration is in the following sectors, namely: breweries, food and beverages, publishing, health care, chemical and paints, oil and gas, aviation/airline, agriculture, building materials, computers, conglomerate, construction and engineering. Overall, these results are consistent with both asymmetric information and agency concerns - more informed rational risk-averse managers with power utility functions to make corporate decisions for their self-interest exercise financing restraint through debt conservative use subject to governance constraints as well as supply of, and demand for, funds.

\section{Acknowledgements}

This paper is an extension of one of the author's Ph.D. thesis at the University of Lagos (Paseda, 2016). An aspect of this paper was a seminar presentation at the Faculty of Business Administration and Academic Programmes' Committee of the University of Lagos. The authors are grateful for the constructive comments and criticisms of the participants. Professors Rufus Olowe, Esther Adegbite, Willie Iyiegbuniwe, Sunday Owualah, Emeka Ezike, Ifuero Osad Osamwonyi and Dr B. Oke get special thanks. The usual disclaimer applies.

\section{Authors' Biography}

Oluseun Paseda is a Lecturer in Finance at the Department of Banking \& Finance, University of Ibadan, Nigeria. He is a researcher in Finance and a Fellow of the Association of Chartered Certified Accountants (ACCA). His research interests include Corporate Finance, Asset Pricing and Climate Change Finance.

ORCID ID: https://orcid.org/0000-0001-6039-1590

Dr Babatunji Samuel Adedeji currently works as a lecturer in the Department of Accounting, Olabisi Onabanjo University, Ago-Iwoye. Nigeria. Recently he completed his $\mathrm{PhD}$ from the Universiti Putra Malaysia. His research areas include Sustainability, Corporate Governance, Small Medium Enterprises and Organisational Behaviour. He has authored and co-authored a total of 75 scholarly works. To his credit are 50 articles published in different renowned journals, 5 textbooks, 4 chapters in books and 20 conference 
proceedings. Some of these scholarly works have been published and accepted in Q1 and Q2 Journals, and renowned international publishers such as Universiti Putra Malaysia (UPM press).

ORCID ID: https://orcid.org/0000-0002-8440-0524

\section{References}

Abor, J. (2008), "Determinants of the capital structure of Ghanaian firms", AERC Research Paper 176, African Economic Research Consortium, Nairobi (March 2008). https://media.africaportal.org/documents/RP176.pdf Adelegan, O. J. (2009), "Investment, financial factors and cash flow from Nigerian panel data", Journal of African Development, Vol.11 No.1, pp.77-108. https://ideas.repec.org/a/afe/journl/v11y2009i1p77-108.html

Adelegan, O. J. and Ariyo, A. (2008), "Capital market imperfections and corporate investment behaviour: A switching regression approach using panel data for Nigerian manufacturing firms", Journal of Money,

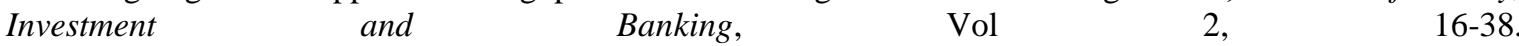
https://www.researchgate.net/publication/228340555_Capital_market_imperfections_and_corporate_invest ment_behavior_A_switching_regression_approach_using_panel_data_for_Nigerian_manufacturing_firms

Admati, A. R. DeMarzo, P. M. Hellwig, M. F. and Pfleiderer, P. (2018), "The leverage ratchet effect", Journal of Finance, Vol.73 No.1, pp.145-198. https://onlinelibrary.wiley.com/doi/abs/10.1111/jofi.12588

Akintola-Bello, O. (2004), The Nigerian Stock Market: Behaviour and Performance, Lagos: Arbitrage Consulting Group.

Akintola-Bello, O. and Adedipe, A. (1983), "Estimating the cost of equity of Nigerian Firms, The Nigerian Journal of Economic and Social Studies, Vol.20 No.1, pp.99-106.

Amah, P. N. (2014), "Revisiting the effects of tax and bankruptcy costs on financing decisions among publicly listed firms in Nigeria", $5^{\text {th }}$ Annual International Conference on the Nigerian Financial System and Inclusive Growth and Development, 1, pp.183-193.

Amah, P. N. and Ezike, J. E. (2013), "Investigating the relationship between corporate growth and debt policy: The Nigerian evidence", Journal of Money, Investment \& Banking, Vol.27, pp.99-113.

Antill, S. and Grenadier, S. R. (2019), "Optimal capital structure and bankruptcy choice: Dynamic bargaining versus liquidation”, Journal of Financial Economics, Vol.133 No.1, pp.198-224. https://www.sciencedirect.com/science/article/abs/pii/S0304405X19300224

Ayyagari, M. Beck, T. and Hoseini, M. (2020), "Finance, law and poverty: Evidence from India", Journal of Corporate Finance, Vol.60, Article 101515. https://www.sciencedirect.com/science/article/pii/S0929119918308022

Barakat, M. H. and Rao R. P. (2013), "The role of taxes in capital structure: Evidence from taxed and non-taxed Arab economies", Working Paper, Oklahoma State University. https://mpra.ub.uni-muenchen.de/25472/

Barclay, M. J. Morellec, E. and Smith, C. W. (2006), “On the debt capacity of growth options”,

Vol.79, pp.37-59. https://ideas.repec.org/a/ucp/jnlbus/v79y2006ilp3760.html

Barclay, M. J. and Smith, C. W. (2020), “The capital structure puzzle: Another look at the evidence”, Journal of Applied Corporate Finance, Vol.32 No.1, pp.80-91.https://onlinelibrary.wiley.com/doi/abs/10.1111/jacf.12390

Begenau, J. and Salomao, J. (2019), "Firm financing over the business cycle", Review of Financial Studies, Vol.32 No.4, pp.1235-1274. https://academic.oup.com/rfs/article/32/4/1235/5087739

Bianchi, F., Ilut, C.L. and Schneider, M. (2018), "Uncertainty shocks, asset supply and pricing over the business cycle", Review of Economic Studies, Vol.85 No.2, pp. 810-854. https://academic.oup.com/restud/article-abstract/85/2/810/3887236?redirectedFrom=fulltext

Black, F. (1972), “Capital market equilibrium with restricted borrowing”, Journal of Business, Vol.45, pp.444454. https://www.jstor.org/stable/2351499

Breeden, D. T. (1979), “An intertemporal asset pricing model with stochastic consumption and investment opportunities”, Journal of Financial Economics, Vol.7 No.3, pp. 265-296. https://www.sciencedirect.com/science/article/abs/pii/0304405X79900163

Buckley, P.J. Chen, L. Clegg, L.J. and Voss, H. (2020), "The role of endogenous and exogenous risk in FDI entry choices", Journal of World Business, $\quad$ Vol.55 https://findanexpert.unimelb.edu.au/scholarlywork/1417700-the-role-of-endogenous-and-exogenous-risk-infdi-entry-choices

Cho, S. and Lee, J. (2020), "Estimating the uncertainty -R\&D investment relationship and its interactions with firm size", Small Business Economics, https://doi.org/10.1007/s11187- 02000346-8. 
Choi, Y. M. Park, K. and Kim, W.S. (2020), "Corporate hedging and dividend policy: An empirical study of Korean $\begin{array}{lllll}\text { firms", } & \text { Finance } & \text { Research } & \text { Letters, } & \text { Vol.32 }\end{array}$ https://www.sciencedirect.com/science/article/pii/S1544612318306378

Choi, J. and Richardson, M. (2016), "The volatility of a firm's assets and the leverage effect", Journal of Financial Economics, Vol.121No.2,pp.254-277. https://www.sciencedirect.com/science/article/abs/pii/S0304405X16301003

Cohn, J. B. Titman, S. and Twite, G. J. (2020), "Capital structure and investor-level taxes: Evidence from a natural experiment in Europe", SSRN Electronic Journal 2941957.

Retrieved May 2020. https://faculty.mccombs.utexas.edu/Jonathan.Cohn/papers/Imputation_2020feb1.pdf

DeAngelo, H. and Masulis, R. (1980), “Optimal capital structure under corporate and personal taxation", Journal of Financial Economics, Vol.8 No.1, pp. 5-29. https://www.sciencedirect.com/science/article/abs/pii/0304405X80900197

DeAngelo, H. and Roll, R. (2015), "How stable are corporate capital structures?”, Journal of Finance, Vol.70 No.1, pp. 373-418. https://onlinelibrary.wiley.com/doi/abs/10.1111/jofi.12163

Demirguc-Kunt, A., Peria, MSM, and Tressel, T. (2020), "The global financial crisis and the capital structure of firms: Was the impact more severe among SMEs and non-listed firms?", Journal of Corporate Finance, Vol.60 No.1, pp. 1-32, Article 101514. https://www.sciencedirect.com/science/article/pii/S0929119918308393

Doidge, C. and Dyck, A., (2015), "Taxes and corporate policies: Evidence from a quasi-natural Experiment", Journal of Finance Vol.70 No.1, pp.45-89. https://onlinelibrary.wiley.com/doi/abs/10.1111/jofi.12101

Elkahmi, R. and Salerno, M. (2020), "How large are pre-default costs of financial distress? Estimates from a dynamic model," SSRN Electronic Journal 3553063. DOI:10.2139/ssrn.3553063 Retrieved May 2020

Eisenthal-Berkovitz, Y. Feldhutter, P. and Vig, V. (2020), "Leveraged buyouts and bond credit Spreads", Journal of Financial Economics, Vol.135 No.3, pp. 577-601. https://ideas.repec.org/a/eee/jfinec/v135y2020i3p577-601.html

Fama, E. F. (2011), "My Life in Finance”, Annual Review of Financial Economics, Vol.3, pp.1-15. https://www.annualreviews.org/doi/abs/10.1146/annurev-financial-102710-144858

Fama, E. F. and French, K. R. (2002), “Testing trade-off and pecking order predictions about dividends and debt", Review of Financial Studies, Vol.15, pp. 1-33 https://www.jstor.org/stable/2696797?seq=1

Fama, E.F. and French, K. R. (2012), “Capital structure choices”, Critical Finance Review, Vol.1, pp. 59-101. https://cfr.pub/published/cfr-002.pdf

Fan, J. Titman, S. and Twite, G. (2012), "An international comparison of capital structure and debt maturity choices", Journal of Financial and Quantitative Analysis, Vol.47 No.1, pp. 23-56. https://www.jstor.org/stable/41499460?seq=1

Frank, M. Z. and Goyal, V. K. (2008), “Trade-off and pecking order theories of debt”, in B. E. Eckbo, (ed.) Handbook of Corporate Finance: Empirical Corporate Finance, 2, Chapter12 (Elsevier/North Holland, Amsterdam). https://pdfs.semanticscholar.org/e05f/12544c3ca1aa47cf2c61ac4c56e4abeb7b03.pdf

Frank, M. Z. and Goyal, V. K. (2009), "Capital structure decisions: Which factors are reliably important? Financial Management, Vol.38 No.1, pp. 1- 37. https://onlinelibrary.wiley.com/doi/abs/10.1111/j.1755053X.2009.01026.x

Gathogo, G. and Ragui, M. (2014), “Capital structure of Kenyan firms: What determines it?”, Research Journal of Finance and Accounting, Vol.5 No.5, pp. 118-125. https://iiste.org/Journals/index.php/RJFA/article/view/11418

Glover, B. (2016) The expected cost of default, Journal of Financial Economics, Vol.119 No.2, pp. $284-299$. https://www.sciencedirect.com/science/article/abs/pii/S0304405X15001749

Graham, J. R. (2000), “How big are the tax benefits of debts?”, Journal of Finance, Vol. 55 No.5, pp. 1901-1941. https://onlinelibrary.wiley.com/doi/abs/10.1111/0022-1082.00277

Graham, J.R. and Harvey, C. R. (2001), "The theory and practice of corporate finance: Evidence from the field", Journal of Financial Economics, Vol. 60, pp. 187-243. https://www.sciencedirect.com/science/article/pii/S0304405X01000447

Graham, J. R. and Tucker, A. L. (2006), "Tax shelters and corporate debt policy", Journal of Financial Economics, Vol.81, pp. 563-594. https://www.sciencedirect.com/science/article/abs/pii/S0304405X06000298

Graham, J. R. and Leary, M. T. (2011), “A review of empirical capital structure research and directions for the Future", Annual Review of Financial Economics, Vol.3, pp. 309- 345 https://www.annualreviews.org/doi/abs/10.1146/annurev-financial-102710-144821

Hartmann-Wendels, T., Stein, I. and Stoter, A. (2012), "Tax incentives and capital structure choice: Evidence from 
Germany", Deutsche Bundesbank Discussion $\quad$ Paper $\quad$ No. 18/2012. https://ideas.repec.org/p/zbw/bubdps/182012.html

Hecht, A. (2019), "How do firms manage their interest rate exposure?” Journal of Risk Finance, Vol. 20 No.5, pp. 501-519. Doi.org/10.1108/JRF-02-2019-0037

Jensen, M. C. (1986), “Agency costs of free cash flow, corporate finance and takeovers", American Economic Review, Vol.76 No.2, pp. 323-329. https://www.jstor.org/stable/1818789?seq=1

Jensen, M. C. and Meckling, W. (1976), "Theory of the firm: Managerial behaviour, agency costs and ownership structure", Journal of Financial Economics, Vol.3, pp. 305-360 https://www.sciencedirect.com/science/article/pii/0304405X7690026X

Kim, H. (2020), "How does labour market size affect firm capital structure? Evidence from large plant openings", Journal of Financial Economics, Available online 4 May 2020, https://doi.org/10.1016/j.fineco.2020.04.012

Korteweg, A. (2010) The net benefits to leverage, Journal of Finance, Vol.65, pp. 2137 - 2170. https://onlinelibrary.wiley.com/doi/abs/10.1111/j.1540-6261.2010.01612.x

Lambrecht, B. M. \& Myers, S.C. (2017) The dynamics of investment, payout and debt, Review of Financial Studies, Vol.30 No.11, pp. 3759-3800. https://academic.oup.com/rfs/article-abstract/30/11/3759/3979428?redirectedFrom=fulltext

Lemmon, M., Roberts, M. and Zender, J. (2008), "Back to the beginning: persistence and the cross section of corporate capital structure", Journal of Finance, Vol. 63, pp. 1575 -1608. https://onlinelibrary.wiley.com/doi/abs/10.1111/j.1540-6261.2008.01369.x

Lemmon, M. L. and Zender, J. F. (2010), "Debt capacity and tests of capital structure theories", Journal of Financial and Quantitative Analysis, Vol.45 No.5, pp.1161 -1187. https://www.jstor.org/stable/27919560?seq=1

Lin, C. Schmid, T. and Weisbach, M. S. (2020), "Product price risk and liquidity management: Evidence from the electricity industry”, Management Science, https://doi.org/10.1287/mnsc.2020.3579 Retrieved May 2020.

Lintner, J. (1965), “The valuation of risk assets and the selection of Risky investments in stock portfolios and capital budgets", Review of Economics and Statistics, Vol.47, pp.1337. https://www.jstor.org/stable/1924119?seq=1

Lotfaliei, B. (2020), "Asset variance risk premium and capital structure”, Journal of Financial and Quantitative Analysis, Vol. 55 No.3, pp. 1-70. https://doi.org/10.1017/S0022109020000228

Lucas, R.E. (1978), “Asset prices in an exchange economy”, Econometrica, Vol.46 No.6, pp. 1429-1445. https://econpapers.repec.org/article/ecmemetrp/v_3a46_3ay_3a1978_3ai_3a6_3ap_3a1429-45.htm

Miller, M.H. (1977), "Debt and taxes”, Journal of Finance, Vol.32, pp. 261-276. https://onlinelibrary.wiley.com/doi/full/10.1111/j.1540-6261.1977.tb03267.x

Miller, M.H. (1995), "Do the M\&M propositions apply to banks?” Journal of Banking and Finance, Vol.19, pp. 483489. https://www.sciencedirect.com/science/article/abs/pii/037842669400134O

Miller, M.H. (2005), “Leverage, Nobel Prize Lecture 1990 Reprint”, Journal of Applied Corporate Finance, Vol.17 No.1, pp. 106 - 111. https://onlinelibrary.wiley.com/doi/abs/10.1111/j.1745-6622.2005.020_1.x

Modigliani, F. and Miller, M. H. (1958), "The cost of capital, corporation finance and the theory of investment", American Economic Review, Vol.48, pp. 261-296. https://www.jstor.org/stable/1809766?seq=1

Modigliani, F. and Miller, M. H. (1963), "Corporate income taxes and the cost of capital: A correction", American Economic Review, Vol.53, pp. 433-443. https://www.jstor.org/stable/1809167?seq=1

Mossin, J. (1966) Equilibrium in a capital asset market, Econometrica, Vol.3 No.4, pp. 768-783. https://www.jstor.org/stable/1910098?seq=1

Myers, S. C. (1977), “The determinants of corporate borrowing”, Journal of Financial Economics, Vol. 5, pp.147-175. https://www.sciencedirect.com/science/article/abs/pii/0304405X77900150

Myers, S.C. (1984) The capital structure puzzle, Journal of Finance, Vol.39, pp. 575 - 592. https://onlinelibrary.wiley.com/doi/full/10.1111/j.1540-6261.1984.tb03646.x

Myers, S.C. (2001), “Capital Structure,” Journal of Economic Perspectives, Vol.15 No.2, pp. 81-102. https://www.aeaweb.org/articles?id=10.1257/jep.15.2.81

Myers, S. C. and Majluf, N. S. (1984), "Corporate financing and investment decisions when firms have information the investors do not have”, Journal of Financial Economics, Vol.13, No. 2 pp. $187-221$. https://www.sciencedirect.com/science/article/abs/pii/0304405X84900230

Oyelakin, A. (2020), "Essays in empirical corporate finance", PhD Thesis, Essex Finance Group, University of Essex. http://repository.essex.ac.uk/27195/

Paseda, O. A. (2016), "The determinants of capital structure of Nigerian quoted firms", unpublished Ph.D. Thesis, Department of Finance, University of Lagos, Nigeria. https://dx.doi.org/10.2139/ssrn.2890900

Renneboog, L. and Szilagyi, P. G. (2020), "How relevant is dividend policy under low shareholder protection?" Journal of International Financial Markets and Institutions and Money, Vol.64, pp. 100776. https://www.sciencedirect.com/science/article/pii/S1042443115000074 
Sarkar, S. (2020), "The relationship between operating leverage and financial leverage",

Accounting \& Finance, Vol.60 S1, pp. 805-826. https://onlinelibrary.wiley.com/doi/abs/10.1111/acfi.12374

Scholes, M.Wolfson, M. Erickson, M.,Hanlon,M. Maydew, E. and Shevlin, T. (2015), Taxes and

Business Strategy: A Planning Approach, Fifth Edition, New Jersey: Prentice-Hall. https://www.gsb.stanford.edu/faculty-research/books/taxes-business-strategy-5th-edition

Sharpe, W. F. (1964), "Capital Asset Prices: A theory of market equilibrium under conditions of risk", Journal of Finance, Vol.19, pp. 425-442. https://www.jstor.org/stable/2977928?seq=1

Shleifer, A. and Vishny, R. W. (1993), “Corruption”, Quarterly Journal of Economics, Vol.108, pp. 599-618. https://academic.oup.com/qje/article-abstract/108/3/599/1881822?redirectedFrom=fulltext

Soyode, A. (1978), "Financing industrial growth in Nigeria: A study of the place of debt and retained earnings", Journal of Management, Vol.101, pp. 26-31.

Strebulaev, I. and Whited, T. M. (2012), "Dynamic models and structural estimation in corporate Finance", Foundation and Trends in Finance, Vol.6, pp. 1-163. https://www.nowpublishers.com/article/Details/FIN-035

Strebulaev, I. and Yang, B. (2013), “ The mystery of zero-leverage firms”, Journal of Financial Economics, Vol.109, pp. 1-23. https://www.sciencedirect.com/science/article/abs/pii/S0304405X13000317

Welch, I. (2011), “Two common problems in capital structure research", International Review Finance, Vol.11 No.1, pp. 1-17. https://ideas.repec.org/a/bla/irvfin/v11y2011i1p1-17.html

Welch, I. (2015), Corporate finance: An introduction, $2^{\text {nd }}$ Edition, Pearson Education International. https://www.amazon.com/Corporate-Finance-Ivo-Welch/dp/0984004955

Zingales, L. (2015), “Does finance benefit society”, Journal of Finance, Vol.70 No.4, pp. 1327 - 1363. https://onlinelibrary.wiley.com/doi/abs/10.1111/jofi.12295 